\title{
1992 Environmental Summer Science Camp Program Evaluation \\ The International Environmental Institute of Westinghouse Hanford Company
}

Date Published

July 1993

Sponsored By the Office of Technology Development (EM-50)

Education Program, U.S. Department of Energy

Office of Environmental Restoration and

Waste Management

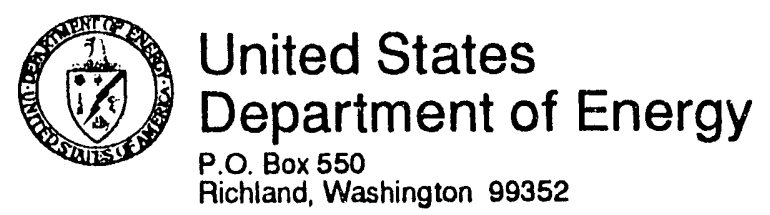


DOE/RL-93-59, Rev. 0

\section{EXECUTIVE SUMMARY}

\section{ENVIRONMENTAL SUMMER SCIENCE CAMP PROGRAM EVALUATION}

The 1992 Westinghouse Hanford Company/U.S. Department of Energy Environmental Summer Science Camp proved to be an exciting experience for everyone involved. The objective of the "camp" was to motivate sixth and seventh graders to pursue studies in math, science, and the environment. This objective was accomplished through hands-on fun activities while studying the present and future challenges facing our environment. The camp was funded through Technical Task PIan, 424203, from the U.S. Department of EnergyHeadquarters, Office of Environmental Restoration and Waste Management, Technology Development, to Westinghouse Hanford Company's International Environmental Institute, Education and Internship Performance Group.

The camp consisted of two one-week sessions. The sessions were held at the Columbia Basin College campus in Pasco, Wasinington, during the weeks of July 13 through 17 and July 20 through 24, 1992. A total of 350 students attended the camp from the Tri-city area (the cities of Richland, Kennewick, and Pasco) and the outlying school districts of North Franklin, Kiona-Benton, and Columbia in Washington State.

The goal of registering at least 50 percent of the campers from the under-represented populations of minorities and females was exceeded. An excellent response from these segments brought the camp to resemble the workforce demographics of the year 2000. 
DOE/RL-93-59, Rev. 0

A representative from the Washington State Department of Ecology joined teams of engineers and scientists from Westinghouse Hanford Company and kindergarten- through community-college-level teachers to collaborate and share ideas, energy, and expertise. The result was an action-packed study tangibly relevant to the curious 11 - and 12-year-old students.

Throughout the two weeks, the Westinghouse Hanford Company scientists and engineers took advantage of opportunities to share skills and knowledge applied in their work. These professionals were an inspiration for the students, teachers, and assistants, and provided excellent role models for students beginning to think about future careers.

Parents were invited to visit on Friday afternoons and participated in various games and lab studies. They also heard the students highlight the week's activities.

Students, teachers, and parents overwhelmingly agreed it was well worth the effort by everyone involved and wanted to know, "How soon can we do it again?"

Immediate survey results indicated that students' attitudes and knowledge of the environment were increased after the camp sessions, particularly in the awareness of job opportunities in environmental areas and demonstrated the students' enthusiasm for the camp. More than half (52 percent) of the participants gave the camp the highest rating possible and nearly three out of four said they were willing to attend future camps. The camp was deemed a success in that several of the goals established prior to the camp were 
DOE/RL-93-59, Rev. 0

achieved. One of these included impacting the way teachers thought about and taught science in comfa.ison to their traditional classroom (i.e., lecturing decreased dramatically during the camp). More extensive results of the survey are included in the appendices of this text. 
DOE/RL-93-59, Rev. 0

This page intentionally left blank. 
DOE/RL-93-59, Rev. 0

\section{CONTENTS}

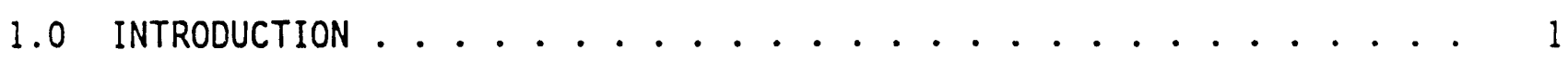

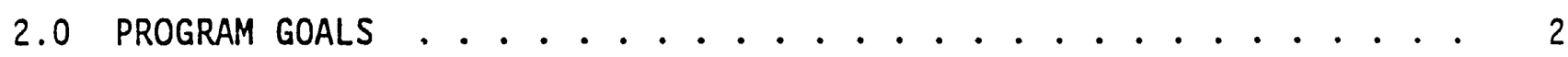

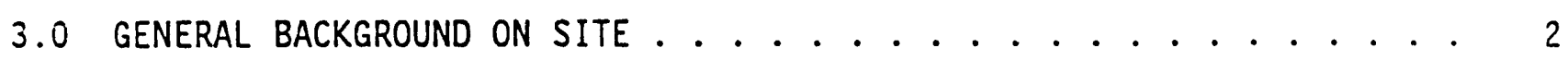

4.0 PROGRAM ACTIVITIES . . . . . . . . . . . . . . . 4

5.0 INSTITUTIONAL PARTNERSHIPS . . . . . . . . . . . . 6

6.0 PLANNING .............................. 8

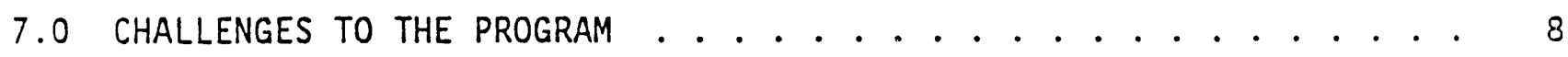

8.0 FUNDING AND BUDGET . . . . . . . . . . . . . . 9

9.0 CAMP DEMOGRAPHICS ........................ 10

10.0 TEACHER DEMOGRAPHICS ..................... 10

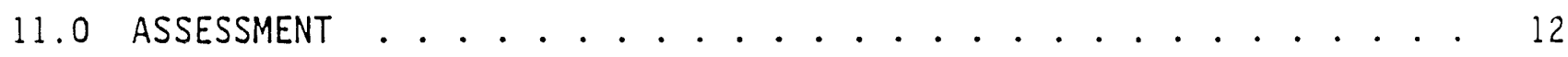

12.0 FUtURE PlanNING . . . . . . . . . . . . . . . . 14 APPENDIXES:

A PUBLICITY/CORRESPONDENCE ................. A-1

B FORMS/APPLICATIONS ................... B-1

C CAMP SCHEDULE ................... . . . .

D LESSON PLAN/ACTIVITY SHEETS $\ldots \ldots \ldots$ D-1

E SURVEY DATA ..................... . . . . . . .

F REPORT OF SURVEY RELATING TO THE SUMMER SCIENCE CAMP $\ldots \ldots \ldots$ F-1 
DOE/RL-93-59, Rev. 0

\section{LIST OF FIGURES}

1 Ethnic Demographics . . . . . . . . . . . . . . . . . 11

2 Gender Demographics . . . . . . . . . . . . . . . . . 11

3 Before Camp Subject Survey . . . . . . . . . . . . . . . . . 13

4 After Camp Subject Survey . . . . . . . . . . . . . . . . 13

\section{LIST OF TABLES}

1 Summer Science Camp Participants By District . . . . . . . . . . . . 7

2 Camp Budget . . . . . . . . . . . . . . . . . . . . . 9

3 Summer Science Camp Teaching Staff Demographics . . . . . . . . . . . 12

\section{LIST OF PHOTOGRAPHS}

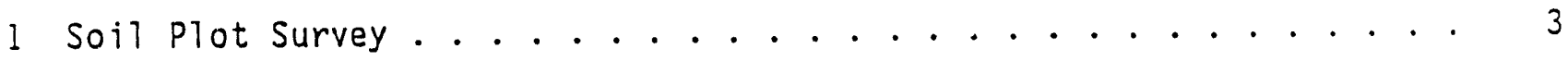

2 Finger Print Laboratory Investigation . . . . . . . . . . . . . 3

3 Water Balloon Toss.......................... 5

4 Avian Presentation .................... . . . . 5 
DOE/RL-93-59, Rev. 0

\title{
ACRONYMS
}

\author{
CBC Columbia Basin College \\ DOE U.S. Department of Energy \\ DOE-HQ U.S. Department of Energy-Headquarters \\ EM Office of Environmental Restoration and Waste Management \\ IEI International Environmental Institute \\ TRIDEC Tri-City Industrial Development Council \\ TTP technical task plan \\ WHC Westinghouse Hanford Company \\ WSU Washington State University
}


DOE/RL-93-59, Rev. 0

This page intentionally left blank. 


\section{ENVIRONMENTAL SUMMER SCIENCE CAMP PROGRAM EVALUATION}

\subsection{INTRODUCTION}

Westinghouse Hanford Company's (WHC) International Environmental Institute (IEI) serves as a central resource for furthering technological and programmatic objectives of the U.S. Department of Energy (DOE)-Environmental Restoration and Waste Management's (EM) Office of Technology Development and the Hanford Site by integrating national environmental education programs with DOE needs and concerns, and hands-on experience.

In 1992, the IEI became the WHC manager of education outreach and programs to encourage the students who will be entering the workforce in and around the year 2000 to seek careers in math, science, and the environment. To this end, the Environmental Summer Science Camp philosophy of hands-on science to engage the minds of young students was developed as a resilt of the success that WHC had experienced with two previous out-reach programs. These two programs, Summer Eneray (1977-1990) and Saturday Science (1991), sponsored by the Hanford Science Center, had been implemented with much success and sought to use role models and engaging activities to capture students' interest and commitment to science, math, and the environment. One of the young women participating in the Summer Energy program pursued her interest generated by the program and, in 1992, became a semi-finalist for the Westinghouse Electric Company national "Science Talent Search" competition.

The partnerships among community agencies and educational organizations created the opportunity for leveraging additional resources in the design and implementation of this "camp." Columbia Basin College (CBC) played a significant role in the success of the camp. The college's Pasco, Washington, campus was selected as the site of the camp because it offers a hazardous materials program, and because it is the local community college that can be the first step that inany students take in their pursuit of higher education. The six local school districts also participated in planning the camp. They were instrumental in the recruitment of teachers and students for the camp. The Washington State Department of Ecology lent its support and expertise by helping to design the curriculum, as well as by providing a teacher for the camp from its local office.

The DOE provided funding for the camp coordinator's, teachers', and teaching assistants' salaries; and materials for the camp. CBC provided the laboratories and equipment needed for aralys is activities, which were conducted. WHC provided the publicity, administrative, scientific, and support personnel for the program. This document evaluates the program and suggests changes for the future. 
DOE/RL-93-59, Rev. 0

\subsection{PROGRAM GOALS}

Public Law 101-510 authorizes DOE facilities to establish programs in science and math. This became a focal point for this camp undertaken by the IEI. The goal for this camp was reviewed and revised by a core team of representatives from CBC, Washington State University (WSU)-Tri-Cities, and the six surrounding school districts. The initial goal established in Technical Task Plan (TTP) 424203 stated that the students would learn more about the present and future challenges to the environment. This initial goal was expanded to include the following student awarenesses:

1. Realize that science is fun and accessible

2. Learn that the study of the environment is science

3. Understand environmental studies apply to the individual as well as to larger groups in society

4. Realize that the Hanford Site is one of the nation's largest environmental sites, undergoins environmental clean-up and restoration

5. Know how our physical, emotional, and economic lives are dependent upon the environment

6. Recogniz's how our actions affect our environment

7. Understand how to take appropriate action on behalf of the welfare of the environment

8. Learn how computers are used to solve environmental problems

9. Become more familiar with career opportunities in environmental areas.

These outcomes were to be achieved by having the teachers work collaboratively on teams with professionals from the scientific community to design, develop, and deliver the curricula that would involve the students in cooperative learning activities and engage them in hands-on/minds-on science.

A secondary goal of the camp was to positively influence how science is taught in local school districts; the concept being that a more creative, innovative approach in the classroom by the teachers will influence a larger student population to enter into math and science fields.

\subsection{GENERAL BACKGROUND ON SITE}

The Pasco campus of CBC was selected as the site of the camp for several reasons. The primary reason is that $C B C$ is centrally located in the Tri-City 
Photograph 1. Soil Plot Survey.

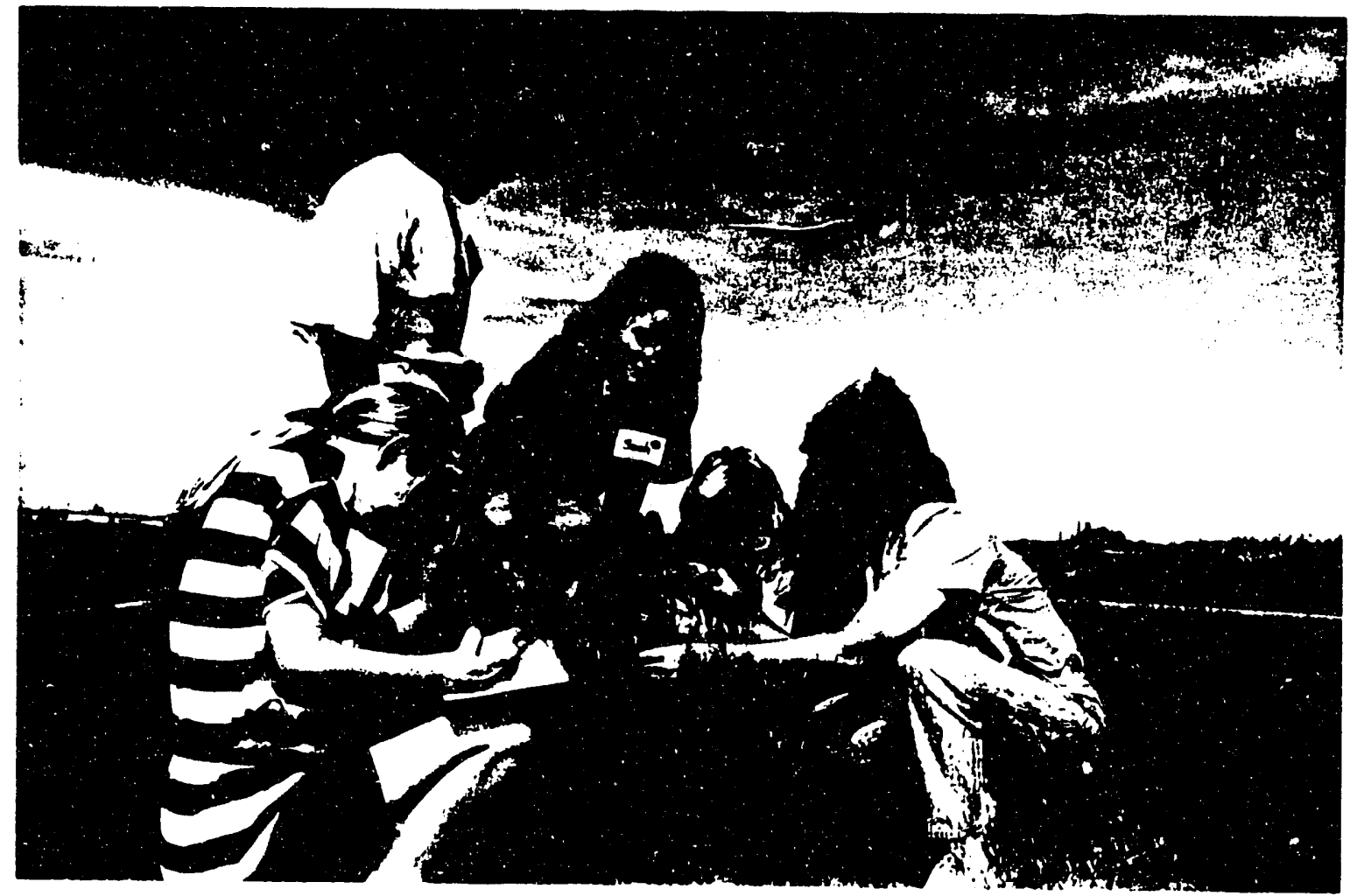

Photograph 2. Finger Print Laboratory Investigation.

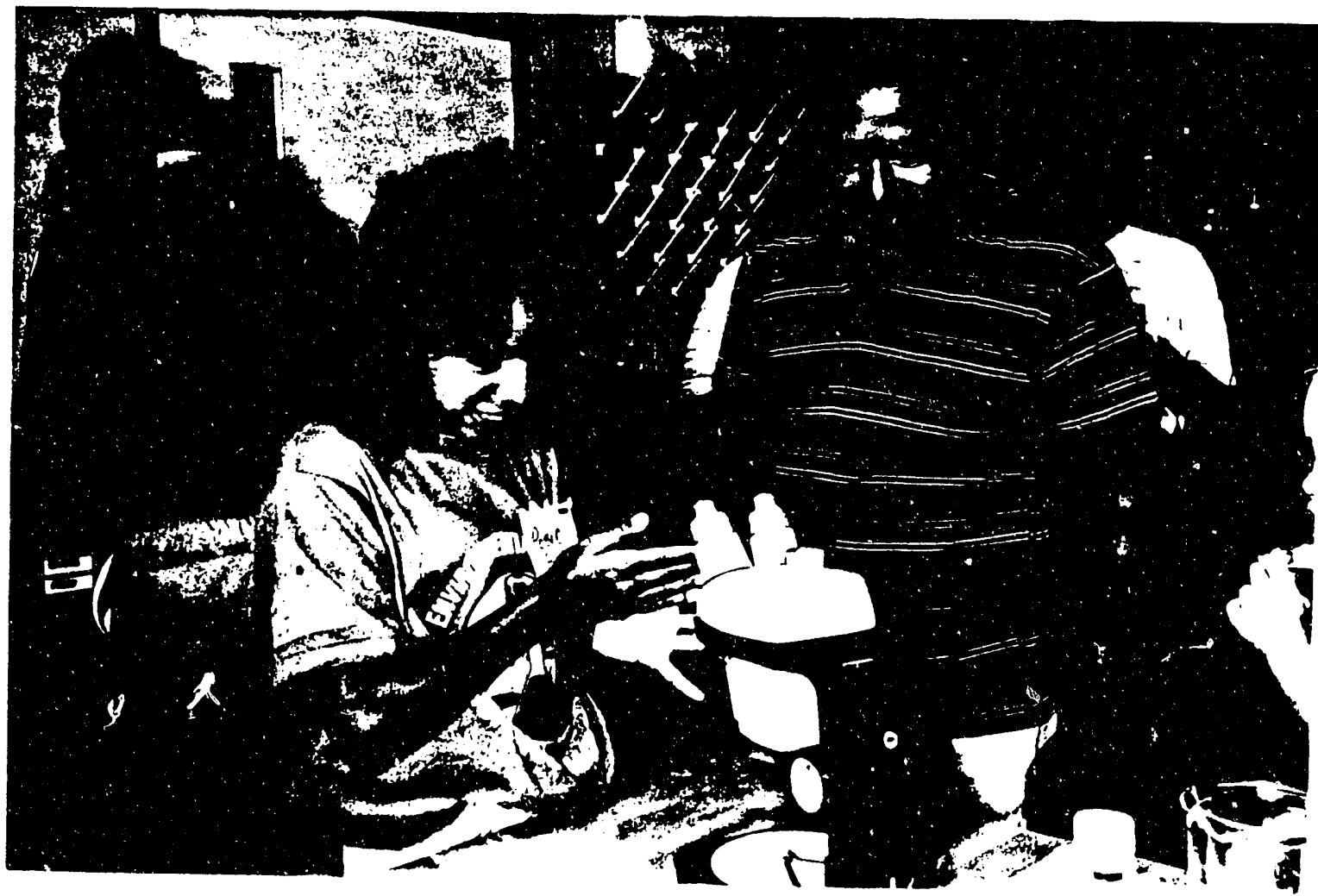


DOE/RL-93-59, Rev. 0

Technology program offered at the college. As such, CBC has an excellent sclence facility and equipment, which it offered to make avallable at no charge to the camp. The equipment helped students to see how a real science laboratory looks and works.

In addition, CBC has accessible, undisturbed 1 and around its campus, which was planned to be used as an outdoor laboratory.

Because at least 50 percent of the population targeted for the camp participation would come from underrepresented populations, it was thought that if these students had a good experlence at the camp on the college campus they would be more encouraged to look to the college as a possibility for their future education. Because CBC is a community college, the tuition costs are much less than those of "our year instltutions and therefore more affordable for many of these students.

There was concurrence in the Idea that if these students experienced success on the college campus at the middle school age, that this experience would positively impact their decision to include college in the ir ruture career plans.

\subsection{PROGRAM ACTIVITIES}

Several action-packed, fun activities were designed for the camp. In a week-long plot study, student/teacher teams examined a specific $15-\mathrm{m}^{2}$ plot of 1 and to determine the relationships of soil, vegetation, weather, and human/animal intervention (Photograph 1). The students compiled their findings in a dally scientific journal whlle comparing their studies to that of the studies completed on the Hanford Site. Activities included conducting a microscoplc study of soll and plant samples, performing chemical analys is of soll, making weather instruments and recording daily weather data, determining the amount of food energy avallable, inferring the ecology of the plot, identifying existing and potential environmental concerns, and suggesting possible resolutions to those concerns.

In other activities, students experimented with dissecting owl pellets and testing the $\mathrm{pH}$ of varlous substances they were famillar with. Matching fingerprints stimulated a comparison of scientific and detective investigations (Photograph 2). Digging chocolate chips out of a cookie was compared to mining. Games, one of which included a water balloon toss (Photograph 3), provlded a means for the students to act out challenges facing their environment.

In addition to hands-on experiences, varlous team activities modeled to the students the value of cooperation and rnllaboration in a work or play situation, which also reflected on the "teamwork" required here at the llanford 
Photograph 3. Water Balloon Toss.

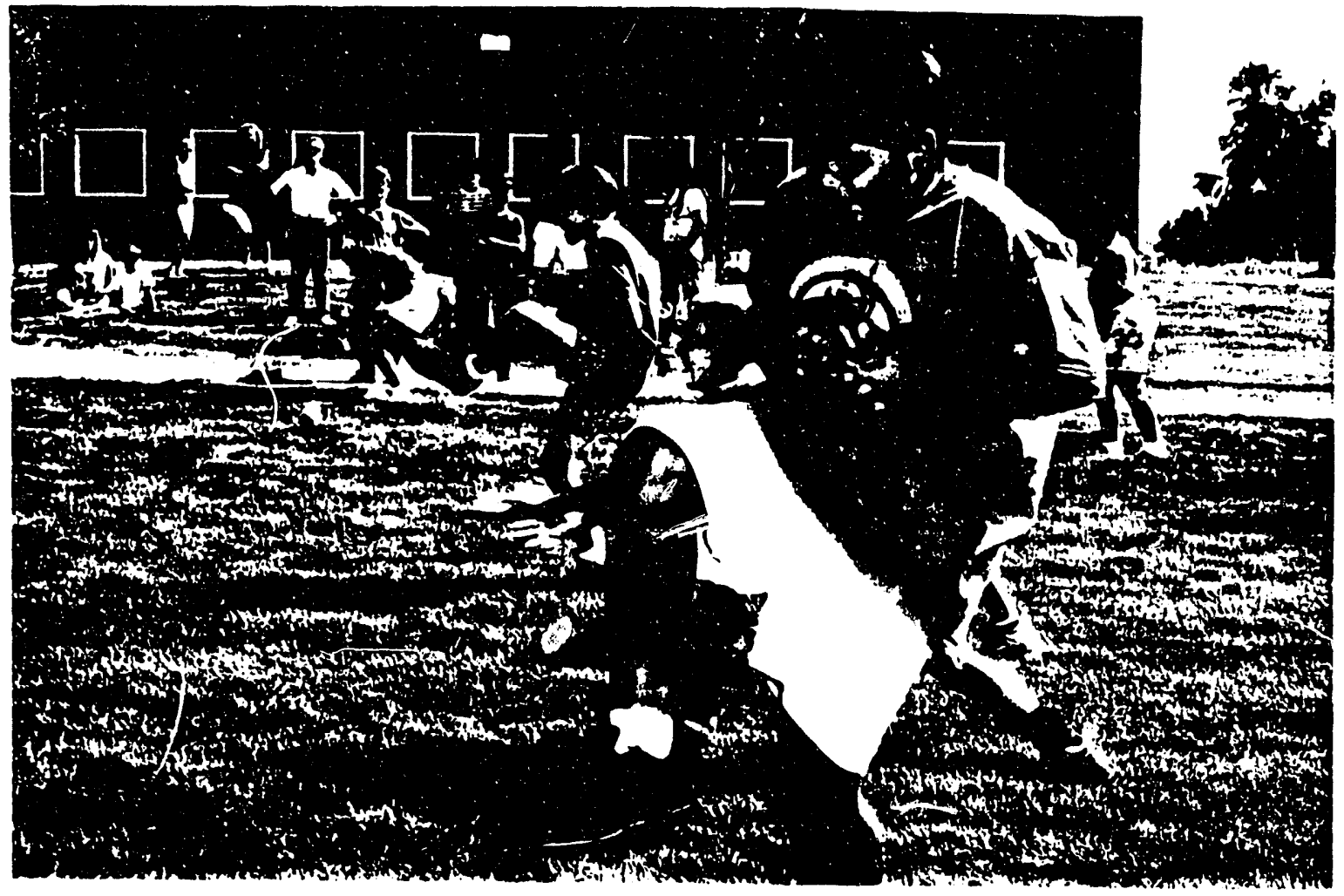

Photograph 4. Avian Presentation

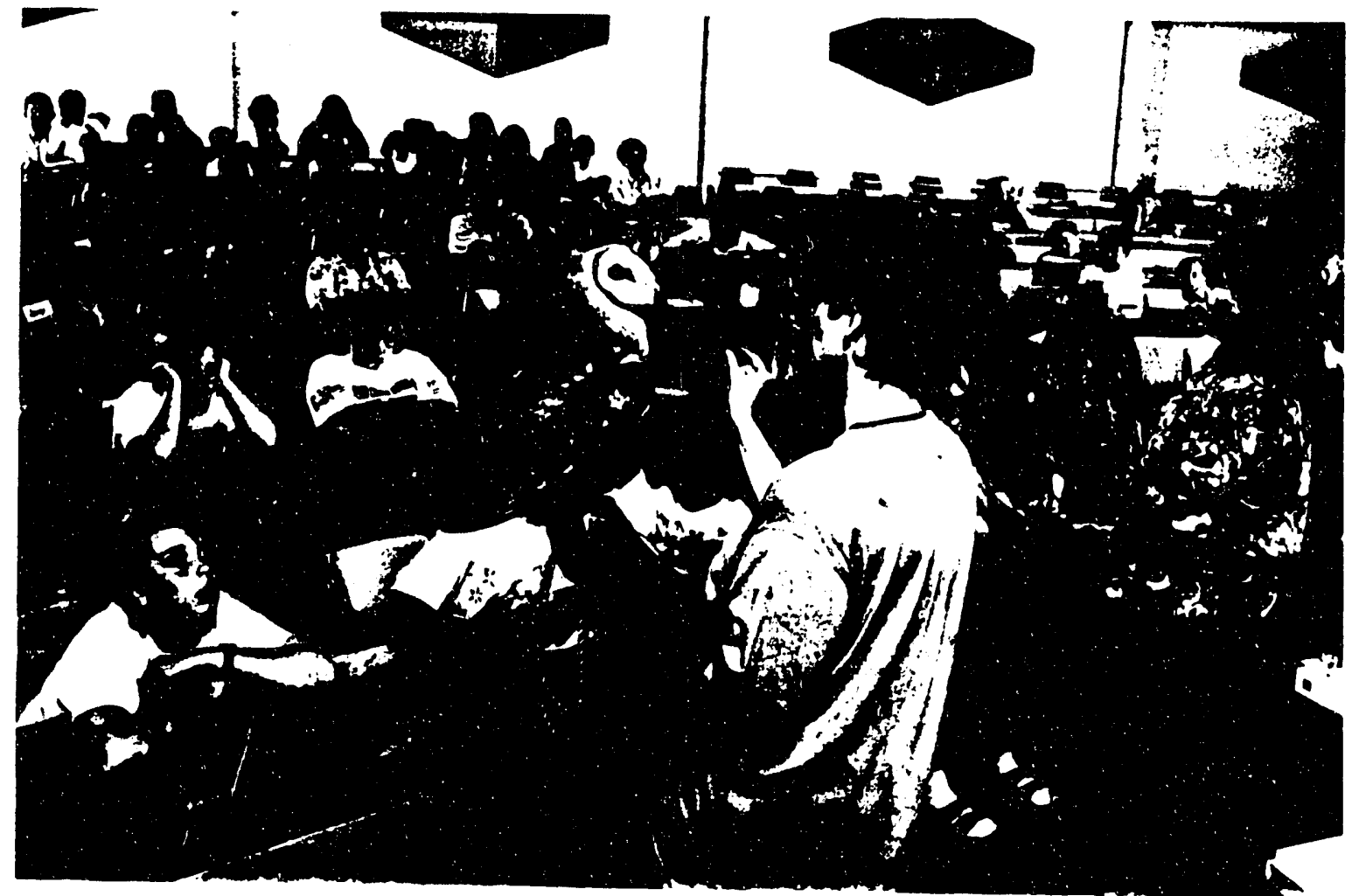


DOE/RL-93-59, Rev. 0

Site. In sharing their expertise and experfence in environmental study, several guest speakers challenged the audience to be informed caretakers of the environment; among these were the following:

- Taffy Mercer, a local falconer, captlvated one and all with her "Birds of Prey" presentation, which included a live owl and hawk (Photograph 4)

- Joe Nevlus and Jim Weber, members from the Tri-City Astronomy Club, highlighted the history of the sun dial and led the students in making simple solar clocks.

- Russell Jim, a Yakima Native American, discussed the Native American perspective on environmental preservation.

- Stu Selbel, a local meteorologist, enlightened the group about the makings of the weather.

- Joe Estey, an environmental manager, challenged the students to develop solutions to hazardous waste by demonstrating a waste problem simulation using vegetable ofl.

Throughout the two weeks, the Hestinghouse Hanford Company scientists and engineers took advantage of opportunitles to share skills and knowledge applied in their work. These professionals were an inspiration for the students, teachers, and assistants, and provided excellent role models for students beginning to think about future careers.

\subsection{INSTITUTIONAL PARTNERSHIPS}

The Environmental Summer Sclence Camp was a result of several successful partnerships. One of the most significant partnerships was with CBC. The college offered its campus, sclence laboratories, and equipment for the use of the students and teachers. CBC also provided significant assistance to the camp by serving as the registrar for the students. A small office was set up for the camp coordinator and teachers where supplies were received and dispersed. CBC provided last minute support to the camp by engaging in a contract with WHC to pay the teachers and purchase the majority of supplies and materials needed for the camp that WHC was not allowed to purchase because of the nature of the contract with DOE.

The IEI provided the administrative and clerical support for the camp. The IEI al so arranged for WHC employees to team with the teachers to plan, design, and Implement the camp.

Funding from the DOE was used to pay the salarles of teachers, teacher assistants, and camp directors, along with the materlals for the camp, a percentage of the cost of the T-shirts given to the students, tuition waivers for those students who were recelving free and reduced lunches at school, and costs of public transit for the students. 
Each of the school districts (i.e., Pasco, Kennewick, Richland, Prosser, North Frankl in, Finley, Kiona-Benton, Columbia and Yakima Native American) were instrumental in recruiting teachers and students for the camp (Table 1). Teachers recommended students (i.e., primarily minority students) based upon students' need and interest. Two of the school districts provided bus transportation to and from the camp with their district buses.

Table 1. Summer Science Camp Participants By District.

\begin{tabular}{|l|c|c|c|c|}
\hline \multicolumn{1}{|c|}{ District } & $\begin{array}{c}\text { Number of } \\
\text { Students }\end{array}$ & $\%$ of Total & Session 1 & Session 2 \\
\hline Kennewick & 1,022 & 36 & 81 & 92 \\
\hline Pasco & 635 & 22 & 53 & 57 \\
\hline Richland & 597 & 20 & 47 & 54 \\
\hline Prosser & 165 & 6 & 13 & 16 \\
\hline North Franklin & 140 & 5 & 11 & 14 \\
\hline Kiona-Benton City & 102 & 4 & 20 & 0 \\
\hline Finley & 100 & 4 & 8 & 10 \\
\hline Columbia & 72 & 3 & 7 & 7 \\
\hline $\begin{array}{l}\text { Yakima Native } \\
\text { American }\end{array}$ & & & 10 & 0 \\
\hline \hline
\end{tabular}

High-school-aged teacher assistants also were hired from MESA (Math, Engineering, Science Achievement) and Upward Bound (a joint program between area high schools and $(B C)$ organizations. These assistants served as minority role models for the younger students as well as providing support to the teachers.

Among the partners involved in the initial planning for the camp, was the Tri-City Industrial Development Council (TRIDEC). TRIDEC was originally to obtain the refreshments for the campers through corporate donation. Because there were only a few students from the Yakima area where many of the food processors are located this effort was not successful. TRIDEC also located additional environmental companies to provide technical assistance to the teachers.

WSU-Tri-Cities was another partner who provided expertise with teacher training for the camp. A WSU-Tri-Cities science educator also provided general direction in the planning phase. 
DOE/RL-93-59, Rev. 0

\subsection{PLANNING}

Upon receiving approval from the DOE to fund the TTP for the Environmental Summer Science Camp, representatives from the Tri-Cities regional school districts, TRIDEC, WSU-Tri-Cities, CBC, and WHC established a core planning committee. Within four months the committee identified the following:

- Summer Science Camp learning objectives

- Targeted population

- Camp dates and location

- Administrative and teaching staff job descriptions.

Thereafter, committee members disseminated information to the public to recruit teachers and students for camp.

\subsection{CHALLENGES TO THE PROGRAM}

There were two major challenges to the camp. The first being the lack of a precedence for the camp. Neither students or parents were aware of the type of camp this was or had any previous knowledge of what the camp could do for kids. Also the turnaround time between the announcement of the camp and the registration for the first camp was limited. (Registration for the second camp went very well as the students and parents had heard about the success of the first camp.)

The first day of the second camp brought an unanticipated amount of students to the campus to register. Because of the large turnout, the class rosters had to be reorganized.

However, the biggest challenge to the camp occurred when it came time to purchase the materials and pay the teachers salaries. The contract between U.S. Department of Energy, Richland Operations Office, and WHC does not allow materials to be purchased for use in educational activities. This was resolved for this camp only when DOE allowed WHC to contract with CBC to purchase materials and pay salaries. Here again, time became a concern as the planning office was not informed of these roadblocks until two weeks before the start of the first camp session. This put a great deal of pressure upon CBC to deliver the supplies and materials in time for the camp.

There also was a delay in the production of the video of the camp because authorization was delayed at U.S. Department of Energy/Headquarters (DOE/HQ). WHC was unable to meet a timeline on the TTP because of this delay. 


\subsection{FUNDING AND BUDGET}

The original funds for the camp came from DOE as the result of a TTP offered by the EM. CBC's in-kind donation was in the form of equipment use, as well as insurance for the campers and use of its facilities, WHC contributed employees' time to help teach during the camp and provided secretarial and administrative support. Because of the necessity to turn to $C B C$ to purchase the materials and pay the salaries of the teachers, it was estimated that the camp budget would be overrun by about $\$ 25,000$.

Additional funds were made available to the camp from an under-run in other TTPS. This was authorized by DOE/HQ. The final cost was much less than what had been projected, and as a result the TTP was greatly underrun for the camp. Table 2 summarizes the expenditures of the budget for the camp.

Table 2. Camp Budget.

\begin{tabular}{|c|c|}
\hline $\begin{aligned} \text { Teaching Salaries } & (18 \mathrm{~K}-14 \text { Teachers } 0 \$ 20 / \text { hour }) \\
& (20 \mathrm{High} \text { School Students } 0 \$ 10 / \text { hour }) \\
& \text { Camp Coordinator }\end{aligned}$ & $\begin{array}{r}\$ 20,800 \\
10,480 \\
2,569 \\
3,994\end{array}$ \\
\hline Total Staff Costs & $\$ 37,843$ \\
\hline $\begin{array}{l}\text { Purchased Services: } \\
\text { Taffy Mercer (avian presentation) }\end{array}$ & 150 \\
\hline $\begin{aligned} \text { Travel (students): } & \text { (Ben Franklin Transit and school } \\
& \text { district busses) }\end{aligned}$ & 535 \\
\hline Food: & 1,269 \\
\hline Supplies and Materials & 10,539 \\
\hline $\begin{array}{ll}\text { T-shirts/Fanny Packs } & \text { (Money expended equal to total } \\
& \text { dollars received from tuition) }\end{array}$ & 4,700 \\
\hline Video/Graphics & 30,200 \\
\hline Adders & 2,580 \\
\hline Administrative Charges & 7,273 \\
\hline Total & $\$ 95,089$ \\
\hline
\end{tabular}




\subsection{CAMP DEMOGRAPHICS}

The initial plans of the coordinating committee were to target only students identified by teachers as potential candidates for the camp. These students were to have been minority and females students. After working with the schools to identify these students it became apparent that we would not be able to meet the targeted number of students through this means.

The camp registration was then opened to all students in Benton-Franklin Counties. Pasco School District, located in Franklin County, has more than 50 percent minorities in its student population. This district was targeted as the area most likely to identify the "sought after student mix." Other schools in the Yakima Valley, just to the west of Benton County, also have a high enrollment of minority students. Registration notices were sent to the school districts in that area as well.

To encourage minority students to enroll in the camp, brochures in both English and Spanish defining the camp were sent to all schools, libraries and community centers in the area. All students recognized by the Hispanic Academic Achievement Programi were sent a personalized letter of invitation to join in the camp. The results of this intentional recruiting was excellent (Figures 1 and 2). Thirty-eight percent of the campers were minority students. Forty-seven percent of the students were females.

\subsection{TEACHER DEMOGRAPHICS}

The teaching staff included 5 WHC scientists and engineers; 1 U.S. Department of Ecology environmental ecologist, 4 CBC math and science instructors, $14 \mathrm{~K}-12$ classroom teachers, and 20 student assistants selected from the Upward Bound program at CBC and high school students from the MESA program (Table 3).

The five WHC employees were all employed in environmental fields at the Hanford Site. Of the $18 \mathrm{~K}-14$ teachers, seven were minorities. A higher percentage of minorities was represented among the high school students who served as teaching assistants; seventeen students represented minority populations. The subjects taught by the teachers during the regular school year were varied; nine taught science (i.e., general science, life science, biology, earth science, and chemistry); seven taught the full spectrum of classes in a self-contained elementary classroom, and two came from language arts and reading subject areas.

The teachers brought expertise and enthusiasm to the planning sessions as well as the actual camp activities. A science education professor from WSUTri-Cities and a Richland High School science teacher engineered the training for the teachers, WHC employees, and teaching assistants. The training as well as the camp was coordinated directly under the leadership of Liz Swinea, Kennewick Community Schools Coordinator. 
DOE/RL-93-59, Rev. 0

Figure 1. Ethnic Demographics.

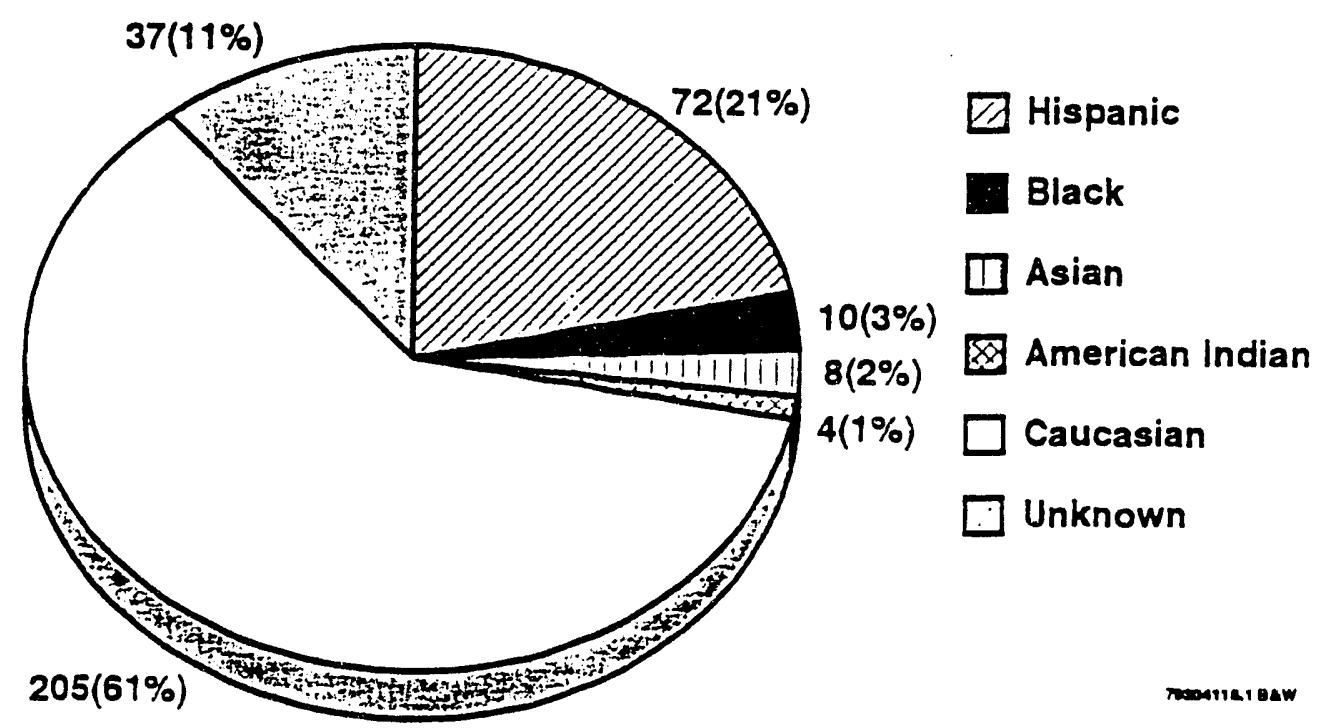

Figure 2. Gender Demographics.

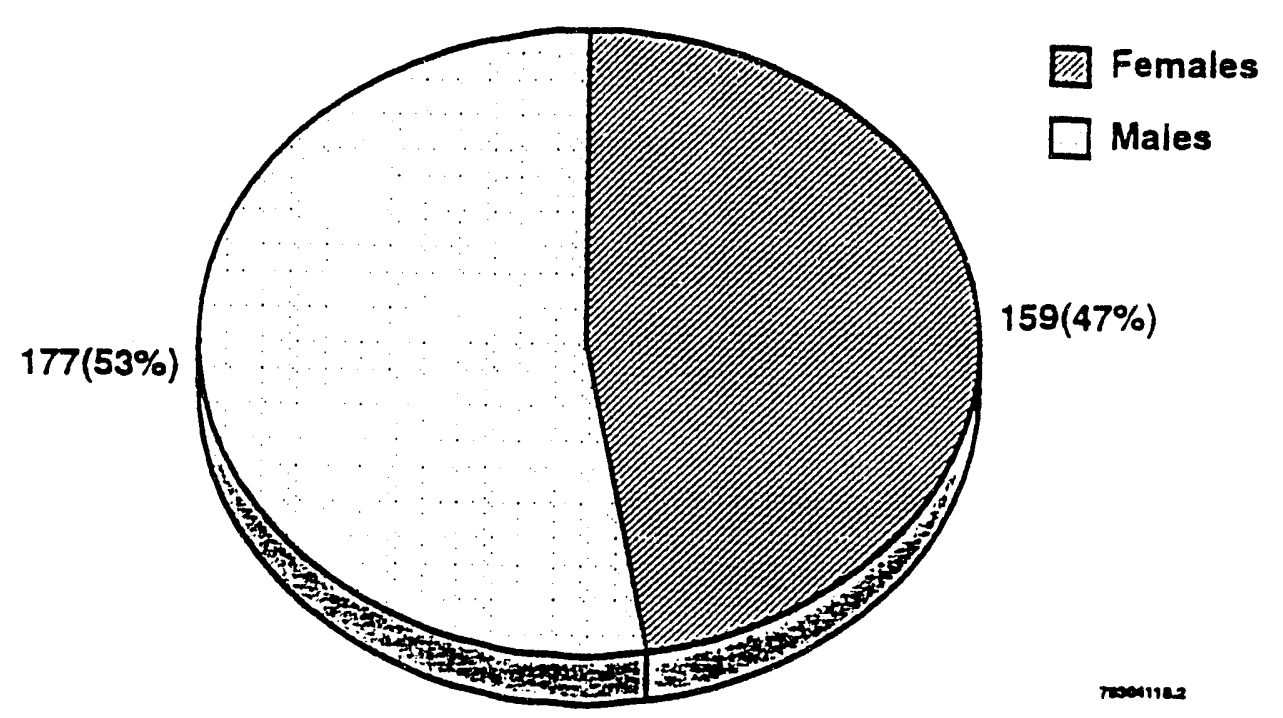


DOE/RL-93-59, Rev. 0

Table 3. Summer Science Camp Teaching Staff Demographics.

\begin{tabular}{|c|c|c|c|c|c|}
\hline & Caucasian & Black & Hispanic & $\begin{array}{l}\text { Native } \\
\text { American }\end{array}$ & Total \\
\hline \multicolumn{6}{|l|}{ Instructors } \\
\hline Females & 8 & 1 & 2 & 0 & 11 \\
\hline Males & 9 & 2 & 1 & 1 & 13 \\
\hline Total & 17 & 3 & 3 & 1 & 24 \\
\hline \multicolumn{6}{|c|}{ Student Assistants } \\
\hline Females & 3 & 2 & 8 & 0 & 13 \\
\hline Males & 0 & 0 & 7 & 0 & 7 \\
\hline Total & 3 & 2 & 15 & 0 & 20 \\
\hline
\end{tabular}

\subsection{ASSESSMENT}

To best measure whether the objectives of the Science Camp (i.e., to change student's behavior and attitudes toward math, science and the environment) two separate survey were conducted. The initial survey was given to teachers, teaching assistants, students, and parents immediately after the camp was held.

To measure the long-term impact of students' attendance at the camp a follow-up survey was conducted in May 1993. The surveys directed the students' teachers and principals to provide data which related to students' grades, attitude toward science, and interest in the study of the environment. The instructions to the teachers were to compare the students' grades at the end of the 1992 spring quarter with those at the end of the 1992 fall quarter in 1992 and compare them to determine if the camp had an impact on the students' academic performance. Other questions were answered by teachers' observation of students' behavior in the classroom. In assessing the students' grades before and after the camp the data collected was factual and limited the potential of social bias from the teachers. An additional survey was taken of the teachers who participated in the camp to determine if their participation had impacted their teaching methodology in the classroom.

The results from both surveys were, generally speaking, favorable. Students' behavior did change positively toward science and the study of the environment and teachers did effect some change in their classrooms as a result of their participation in the camp (Figures 3 and 4 ). Based upon the surveys, it is the recommendation of the IEI that this camp be continued through the support of DOE and other environmental companies in the Tri-City/ Hanford Site area. The long-term goal for sponsoring other camps is for this program to become the Environmental Summer Science Camp for the nation given 
DOE/RL-93-59, Rev. 0

Figure 3. Before Camp Subject Survey.

What is your favorite subject in school? (Before Camp)
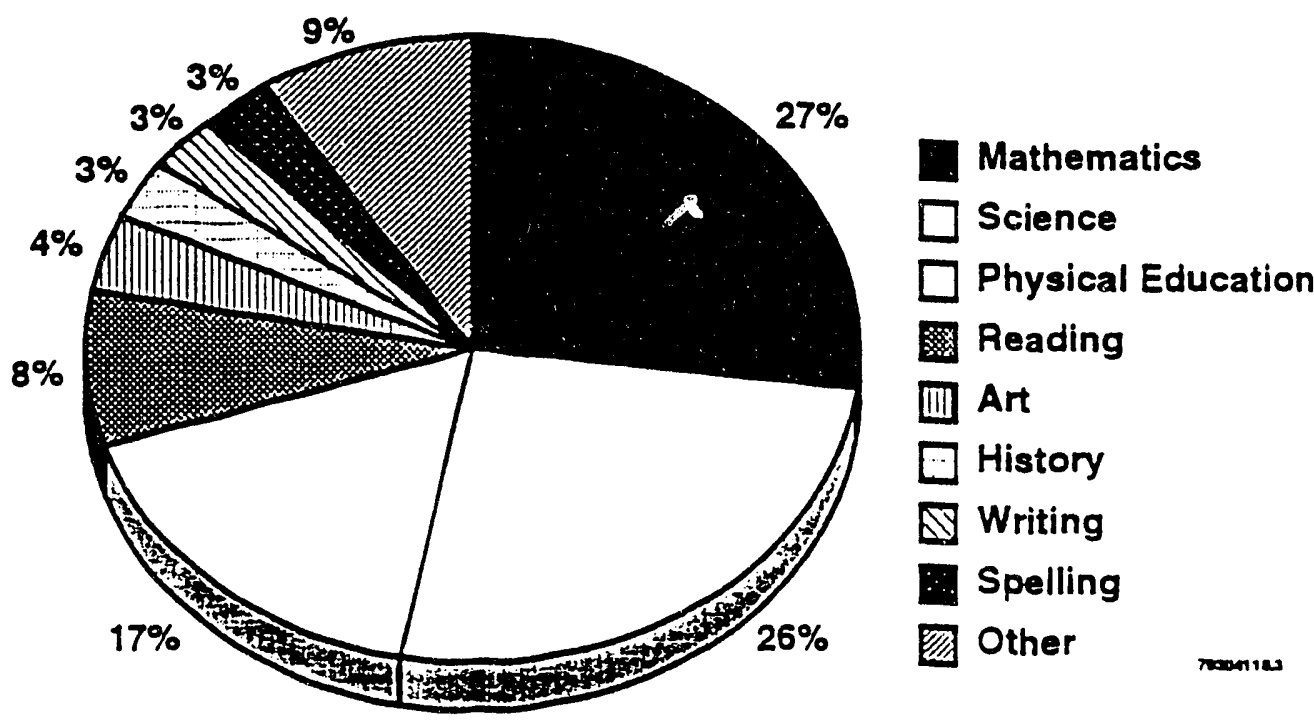

Figure 4. After Camp Subject Survey.

What is your favorite subject in school? (After Camp)

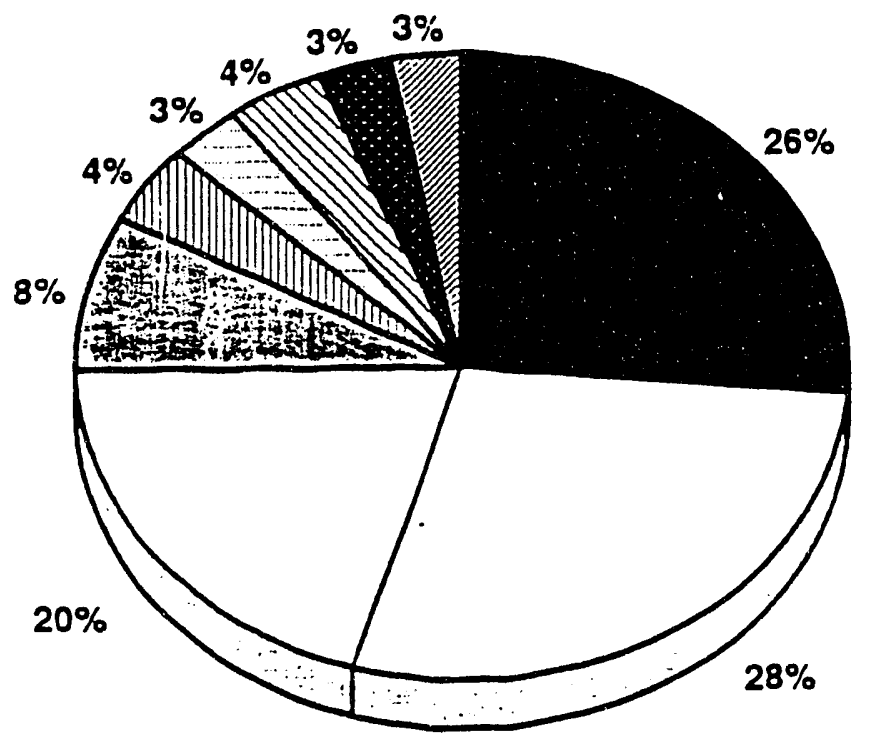

Mathematics

$\square$ Science

$\square$ Physical Education

[i] Reading

IIII) Art

$\square$ History

Writing

Spelling

Other

rearim 
the mission at the Hanford Site. This program, in essence, would become what the NASA Space Camp Program has become for the National Aeronautics and Space Administration.

\subsection{FUTURE PLANNING}

In planning for future summer science camps several realizations were made. The planning for the camp should be started at least five months prior to the first session to allow sufficient time to recruit teachers and involve them in training, recruit potential students, order materials, and develop curriculum.

Funding for the camp from other sources to supplement and eventualiy lessen the dependency on the DOE. Other sources could include environmental engineering firms in the Tri-City area, environmental firms who are subcontractors to the Hanford Site, the Washington State Department of Ecology, U.S. Environmental Protection Agency, and U.S. Department of Agriculture.

Students attending the camp should be encouraged into other WHC programs and eventually into the student work study programs available to high school students to serve as role models for potential camp participants. 
DOE/RL-93-59, Rev. 0

APPENDIX A

PUBLICITY/CORRESPONDENCE

A-1 
DOE/RL-93-59, Rev. 0

This page intentionally left blank. 


\section{"CAMPAMENTO DE CIENCIAS DE VERANO"}

Este campamento es unn oportunidad inica parn estudlantes del sexto grado (: partlr de 9/92) para aprender ntis acerca de los desanos presentes y futuros a que se encaran en el medin amblente a través de una scmar de sesión de clases por la tarde (1:00-4:00) que se llevarín a cabo en el Colegio de Columbia Unsin (CBC) del 13 al 17 de jullo, y lel 20 nl 24 de julio. El personnl de instrucción de este compamento está representindo por un conjunto de tres, un maestro del sistemn de K-12, un ingentern o cientifico ambiental de la compañía de Westinghouse Inonfurd, $y$ un miembro de la facultad de ciencias o del persumal de computaclion del Colegio de Columbin Basin.

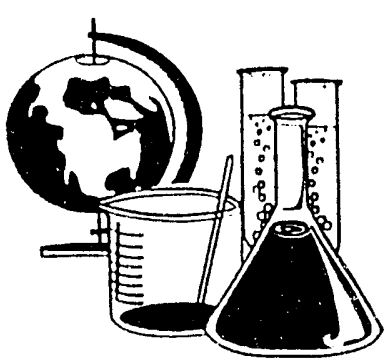

Esla nulorización no cubre una clrugla mayor a inenos que ia spirión do olros dos médicos o dentistas, conilimando la necosidad para lal clugla, sea oblenida anles dse que se nevo acabo la elrugla.

Hochos concomiantos a la hislorla mécica dol nino(a), incluyando alerglas. madlcaclonas que esta lomando y cunlouler Impedimento lisico o Incapactdad mayor do las cuales neceslta

Flima del Padie/Tutor Fecha

RECHAZO DE CONSEMTIMIEHTO PANA LA AUTORIZACION EN EMERGENCIAS MEDICAS

Yo no doy ml consentimlento para que se le de lialamlento a $\mathrm{ml}$ hilo(a) en una omergencla medlea. En ol caso de que ocurrs una entermedad o un accirente que requlera de alención medica. es mi doseo qua las autorldades no tomen ninguna acclón o que:

Firma del Padre/Tutor Fecha

Maesiros: ror lavor. devuetwan este lormulario antes del 1 - do lunlo, 1992 a: Donna Camphort. CBC, 2600 N $201 \mathrm{~h}$, Pasco. WA 99301 richland, wA 99352

TORMULAIIIU OE EXOHERACION

En baneficio de los padies, wiores, yo esloy de ncuerdo de que ro no

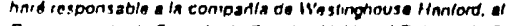
Onparliamento de Energia dn Estados Untios al Colegio de Columbia Basin, ni sus agentes o emplesdos por ninguin ecxidente o haridas que - suliten a cinusa de la participacado de mitho(a) dotrante el periodo de ampo descrilo en esta inseripadn.

FInMA

FECIIA
FONMULATIO dE IHSCTIFCION PATA EL ESTUdIANiE

Instrueclones: No se atrase. Las solkituries son procesadas contorme vayon togando. Inscribnse lo antes pusitio para nsequr irse da que su

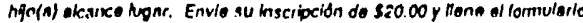

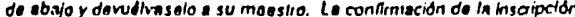
de su hifo(a) serd enviada por correo antes del comienzo de la clase. Si cancela su inseribeidn. to liene que hacer por to menos una semana anles del primer die del canpamento.

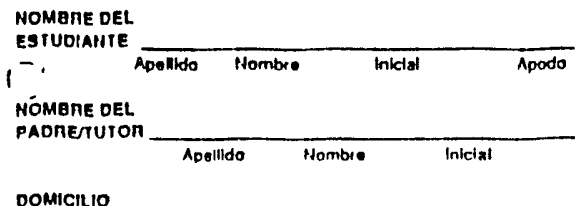

Cnile Cludad Esindo Codgo Posingl

TELEFONO DE CASA

TELEFONO dE inABAJO

INSCRipcion pana (Seleccionn una) SESIOH 1
13.17 IחN2 SESION 2

OTADO OEL ESTUDIAUITE (anirando on septientbie, 1992$)$ ESCUELA

Escuele Distitio

HOMENE DEL MAESTINO DEL ANO 1991.92

- AAD del EgTUdiaHIETECHA dE HACIMIENTO HOMBNEMUJEN

IIINFONMACION DE INSCRIRTICH IMATUITAIII

La donactón que sn rectid dal Departamento de Energla nos parmillse oliecar inscrbodón gratulla a un número Ilmilado de esturianies do lamillas de balo ingreso ncondmico. Ln inlormnclón provalda nhalo nns nyudarA a lomar mueslia dectsión sobre esloe preinlos. Sollo los esludianies que reciben la ayuda de almuerzos gralullos sor in considerados

Pura que su hilo(a) sea considerndo(a) pore in inscibción graluita, uds.

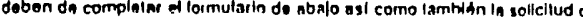
campamento en el lado inverso. Aseguirense do que los masstro o dilictor de sus hipos(as) nermen al lormulatio. Devualunn ell lormulario al manstroial de su hifo(A) anies dal lo de (umio, 1992, pare ser consiberndo(n) pas Inscribedon ginluila.

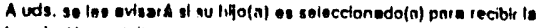
inscripetion gratultis.

IMFORMACION DOMESIICA

El numero lolel de los miembroe de la temille durente 1092 aet in

Inlormaclón de ingreso

1. LEsta coctblendo gu hilo(o) oetualmento aruda con los

1.

2. ¿Que centidad? Merque uno:

and

:

Cortilicacion: Todala intormacion de orriba do cesce lormulatio es verdadare y comple in, hasts la medida mnyor de ini conocirninnio. Yo do

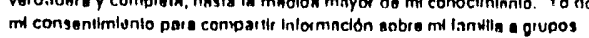

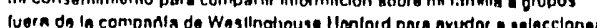
las annidores de becas.

rinsen

$$
\text { PADRE/TUIOON }
$$

FECIIA

B. declanacion

Yo esioy de acueido. Eslo estudania ceciba ayuda para almuerzo en

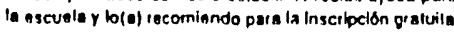

FInMA

$$
\text { Msestro o Direcior }
$$$$
\text { Teidiono }
$$

792051002
tALLA de CAMAISA del EgIUdiante:

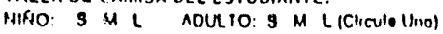

HECESIDADES ESTECIALFS DEL EBIUDIANIE

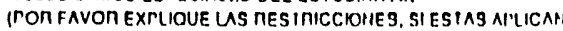

DIEIA:

ME DICINA:

RELIGION:

MOBILIOADIACTIVIOAD:

YO ME HANE CAMOO DE LA IMANSPOHIACIOH OE MI IIIJO PATA ASISIII AL CAMPAMENIOESCOLAR

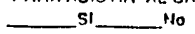

FORMULARIO PATA LOS PADTES DE AUTORIZACIOHEII EMENGEHCIAS MEDICAS

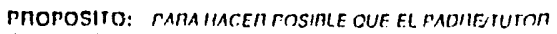
AUTOMICE TMATAMIIFNIO FATA SUIIUO(A) SI SE ENFFRMAA OSE

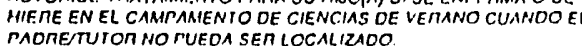

En ol caso do que so hingan hecho osluerzos rasoriables para localizarme at (numbro de tolstonn) y éslos han lallado. yo doy aqul mil consentlimlento nara:

1. La adminlslıaclón de cualquler lratamlennio quo sen necesano segun (dnciniddentisia) D. quio el caso do que el doctor pielerifo que la lia skjo designado mo esı́e disponibla. por olro doctor o denilsta.

2. La liansferencla del nirio(a) a thospitis o a cualquinr olro hospital inzonabiemenio nccesible.

La Companiia Westinghouse IIanford y el

Departamento de linergia de E.U. Les invita a el

Campamento de Ciencias de Verano 1992 cII

\section{El Colegio Cyiumbia Basin (C.B.C.) Pasco, Washington}

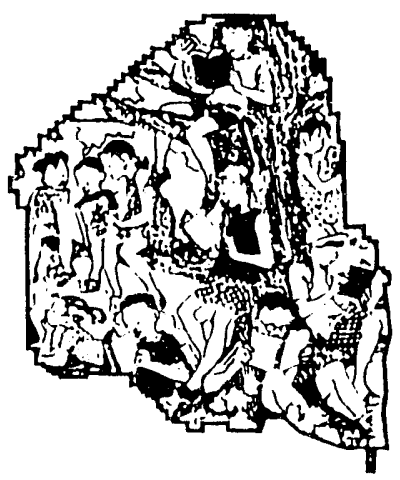

Brochure for Spanis i-speaking Students. 
TO: Hispal.ic Academic Achievement Program Award Recipients

FR:M: Westinghouse Hanford Companyius Department of Energy

RE: Environmental summer Science Camp

DATE: June 22, 1992

\section{Greetings!}

The Westinghouse Hanford Company congratulates you on your academic achievement this year. You are models of excellence for your peers. You are tu be commerided on your performance!

We are planning a summer science camp at Columbia Basin college with students like you in mind. It will be an ACTION-PACKED week of ACTIVITY and FUN related to environmental science. We invite you to attend.

You have a choice of two weeks - July 13th to 1\%th, or July 20 th to 25 th - from 1:00 to 4:00 p.m. Transit passes will be provided for your convenience. The cost for camp is $\$ 20.00$. However, scholarships are available, so don't let that prevent you from signing up.

We hope you'll sign up right away. It's first come first served, so send your registration in today! The deadline for registration is July 6th. (Clecks should be made payable to $C B C$, please.)

We're looking forward to a great week with you!

If you have any guestions, call Liz at 736-2666.

Invitation to Hispanic Academic Achievement Award Recipients. 
DOE/RL-93-59, Rev. 0

\author{
Applicant's Name \\ Address \\ May 26, 1992
}

\title{
Dear :
}

Thank you for expressing interest in the Environmental summer Science Camp. You have been selected as an instructor. You will be working with a team consisting of one Westinghouse

scientist/engineer, one CBC instructor, one $\mathrm{K}-12$ teacher (you!), and two student assistants with 25 students. All that expertise and energy will be dynamic. It will be exciting!!

As you know, the two summer camps are scheduled for July 13-17, and July 20-24 from 1-4pm at CBC. Inservice training will happen Saturday, May 30th, and Saturday, June 13 th at the CBC Science Building Room , from 8:30am to 4:30pm. A general program description and the agenda for the first inservice are enclosed.

I look forward to working with you. please call if you have any questions.

sincerely,

Liz Swinea

Program Coordinator

$736-2666$

Teacher Acceptance Letter. 
DOE/RL-93-59, Rev. 0

TEACHER BULLETIN

WEER 1 BCIENCB CAMP

JulY 15, 1992

Science camp is going great -- thanks to you folks. Despite the rough start on Monday, last minute room changes, and several key supplies not being available, you have worked wonders. Thanks a milition!

PARENT VOLUNTEER: Did you know that we have a parent volunteer? Jan Dickenson (Billy's mother) is disseminating the treats and ice daily. She also organized our temporary office of supplies. She's helping me with other office work. Please let her know her service is appreciated. Our hats are off to you, Jan!

CBC SECRETARY: Lupe has gone out of her way to accommodate our needs this week. I understand she'll be on vacation next week. Please express appreciation to her, too. Thanks, Lupe!

SURVEYS, TESTS, LESSON PLANS: If you have not already, done so, please hand in your Westinghouse surveys. I'll collect your pre and post test.s on Friday. I will also need you lesson plans for my final report. I appreciate the time and energy you have given to doing them.

BUS SCHEDULE: Thanks for getting kids to the bus on time. I understand it leaves the CBC stop at 4:05. Some students need to be there at 3:55 to catch a bus to Richland. Thanks for cooperating in dismissing students in a timely manner.

GRAND FINALE: Parents are invited to attend the closing "grand finale" on Friday. What happens during that segment is up to each group. Ice cream will be served to everyone. Notes need to go home with kids today. I'll ask for a prospective count on number of parents coming tomorrow.

SUPPLIES: Please let me know what supplies you need for next week -- that is, supplies that need to be replenished (or initially provided, as the case may be). I'll do my best to locate and purchase what is needed.

\section{DAILY TREATS: Are they satisfactory? Suggestions for next week?}

STUDENT ASSISTANTS: Your team leaders are bragging about you! Thanks for your leadership and initiative. You are making a positive difference. Please be visible at the bus stop at 4:00 and before and after camp (in front of the math/science building) to help supervise kids. Parents have been told that you will be there for kids from 12:40 to 1:00 and 4:00 to 4:20. Thanks!

"The basic energy of people comes from creative capabilities, from their: ideas, and from their trust in one another." -Anonymous

Keep on keeping on!

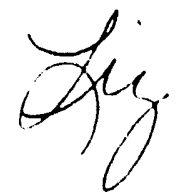


Tri-City Herald Article (July 1, 1992).

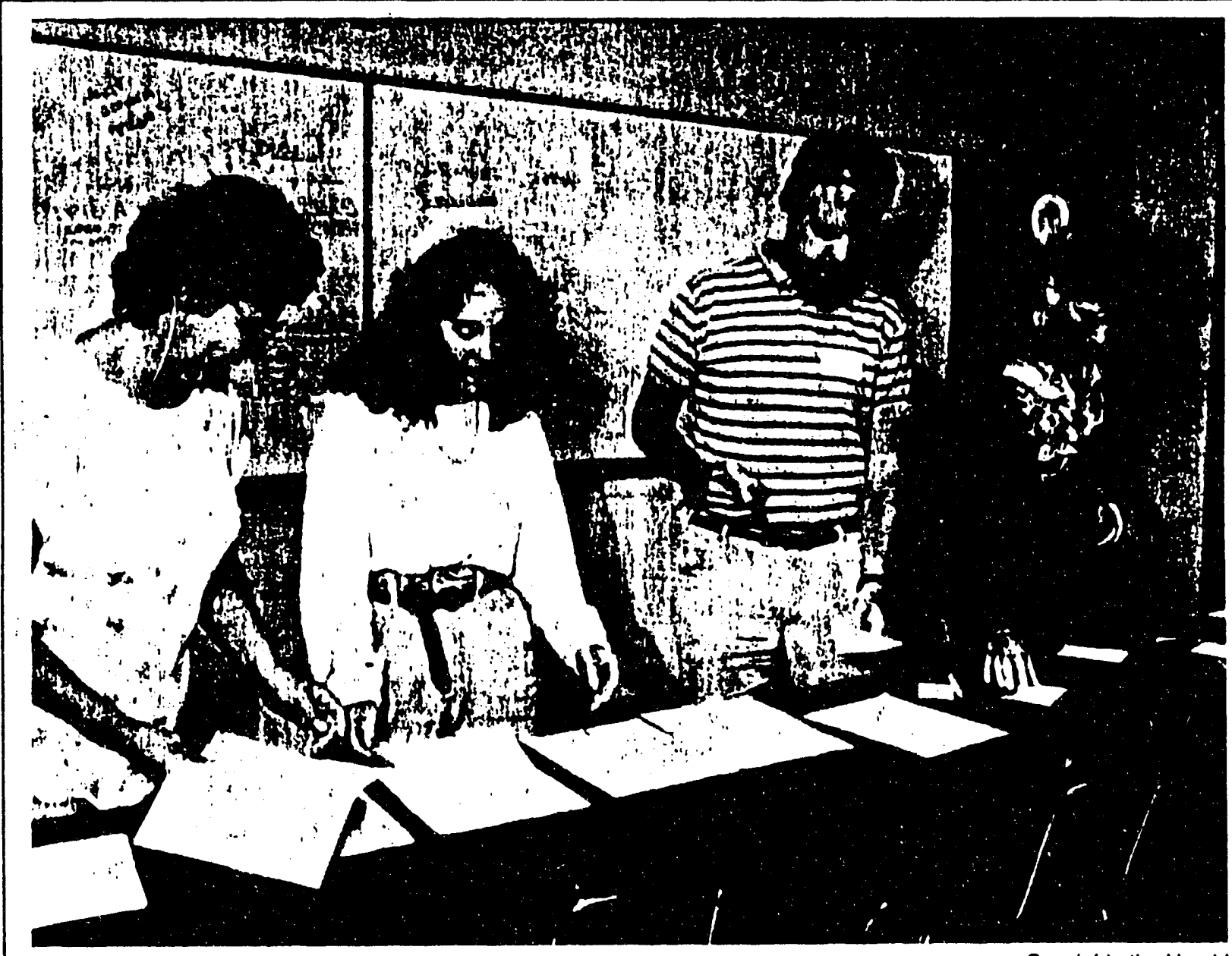

Assembling material for the first Environmental Summer Science Camp are, from left, Sylvia Rivera from Robert Frost Elementary in Pasco, Susan Schultz of Westinghouse Hanford, Brian Monk of Edison Elementary in Kennewick and Liz Swinea from the Kennewick Community School program.

\section{Summer science camp to open}

The Tri-Cities' first Environmental Summer Science Camp will offer children in Benton and Franklin counties a chance to learn about the environment and have fun doing it.

The camp will give sixth-and seventh-grade students a "hands-on study of the environment," sald Gwen Leth, education specialist with the Education and Performance Group at Westinghouse Hanford Co.

The program includes taking soil and water samples, talking with Indians about their view of . the environment, and visiting with a falconer who will bring a live owl and hawk.

Westinghouse scientists and engineers will join Tri-City teachers and Columbia Basin College faculty members to teach the summer program. The camp is sponsored by Westinghouse and is funded through the U.S. Department of Energy. The Department of Ecology also will participate in the program, Leth said.

Two sessions wiii be offered, one from July 13-17 and the oth- er from July 20-24. They will be held from 1 to 4 p.m. at CBC. The cost is $\$ 20$, but students who have been on free or reduced lunch programs are eligible for camp scholarships.

Those interested must register by July 8 . There are 250 spaces available in each session, and applicants will be accepted on a first come, first served basis.

Applications are available at the CBC bookstore, the Hanford Science Center in Richland or by calling $\mathrm{Liz} \mathrm{S}$ winea at 736-2668. 
BY FAY TOLLEY

Herald stall writer

Melanie Cofrey Iigures one good school course deserves another.

And so the St. Joseph's School sixth-grader signed up for a repeat of the science camp being of fered to area sixth-and seventhgraders at Columbia Basin College this week.

"It was so much fun, and learned lots," the Kennewick youth said.

On Monday, the daughter of Sheila and Michael Coffey joined about 100 youngsters to hear falconer Taffy Mercer explain how birds must adapt to survive.

On opposite sides of the room perched "Windy," a red-talled hawk, and "Trilby," a nearly bllnd barn owl.

Melanie, 11, already knew about the birds by the time she had finished her first round of weeklong classes July 17.

In other rooms at the Pasco campus, another 200 middle school students were studying soil and humidity, animals, vegetation, as tronomy and mete.orology.

They are enrolled in the area's first Environmental Summer Science Camp sponsored by the Education and Internship Performance Group of Westinghouse's International Environmental Institute.

It is funded by a grant from the Department of Energy and taught by area teachers and Westing. house Hanford engineers and scientists.

Mercer I: director of the Falconhurst Raptor Rehabilitation and Environmental Education Center in Kennewick. Melanie was among the 300 students who attended the identical course last week.

\section{camp attracts youngsters}

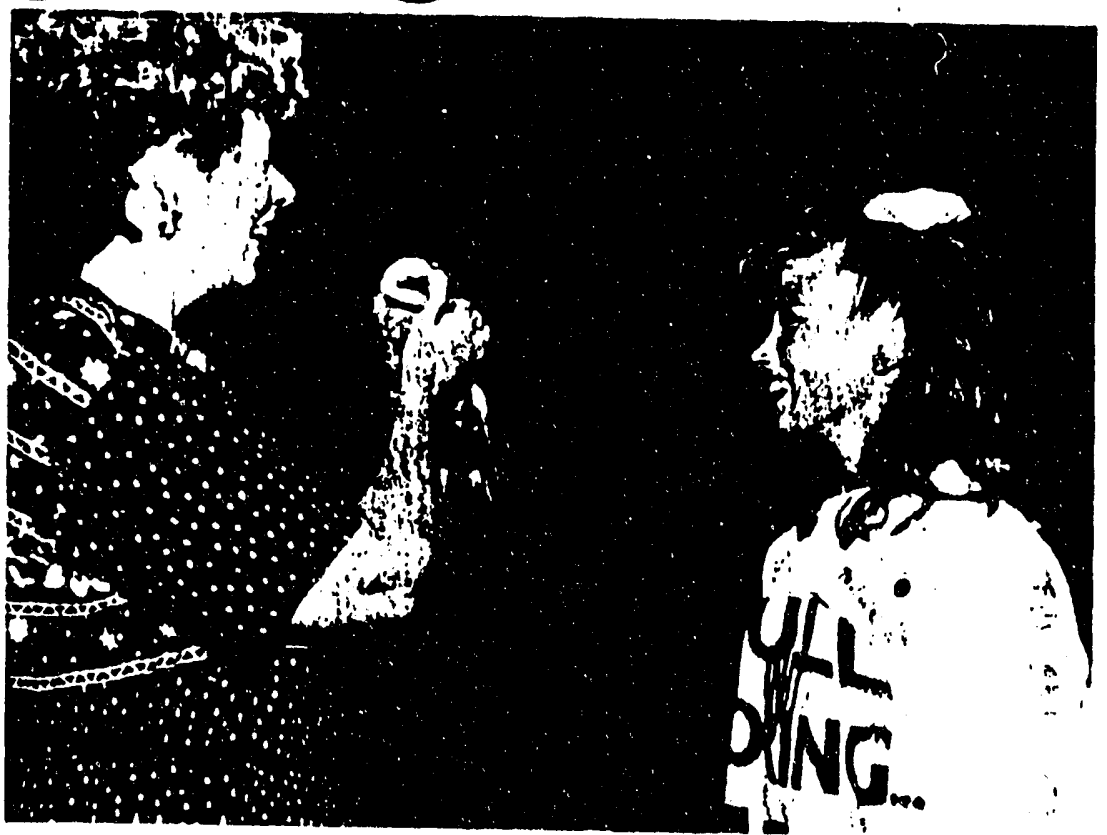

Herald/Dorothy Adcock A barn owl nips at Tabby Mercer's finger during an environmental science camp at Columbla Basin College. Melanie Coffey, 11, a student at St. Joseph's Catholic School in Kennewick, laugh's with Mercer, who is director of Falconhurst Raptor Rehabilitation in Finley.

But there was no boredom in the day's repetition, she said. Perhaps someday she might be one of the scientists who is quallified to talk about birds, she said with a shy grin and a shrug.

She learned that while "Trilby" had only hatched a few months ago, the bird is severely handicapped by cataracts after being fed raw hamburger by unknowing captors.

The owl's soft, rounded feathers allow her to fly silently and undetected during a nightly search for food, Mercer said.

But "Windy's stifr, pointed wings can howl in flight because hawks are naturally equipped for speed in thelr daytime prowls", Mercer said.

With a little poking around, the students learned about Trilby's previous day's meals by examining an owl pellet. Arter Trilby downed food into its gizzard in a single gulp, including bones and fur, she regurgitates the unwanted leftovers in tidy pellets.

"This is cool," Tommy Lafontaine, 12 , said quietly as the class neared its end. "It's neat to see the difference between the birds. I'm here because I want to learn about the environment."

The son of Michelle Lafontaine attends Desert HIlls Middle School In Kennewick. 


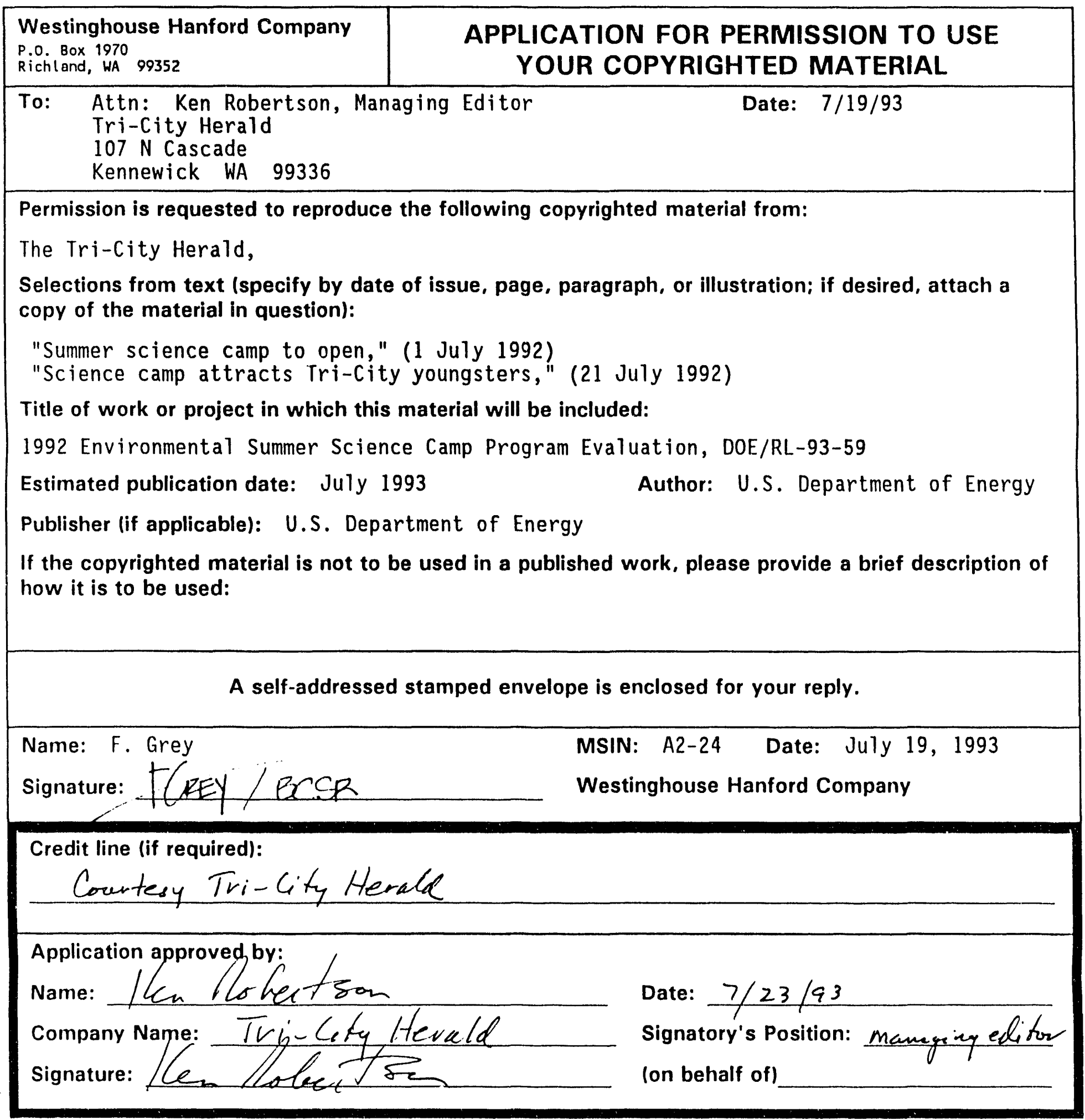


DOE/RL-93-59, Rev. 0

APPENDIX B

FORMS/APPLICATIONS

B-1 
DOE/RL-93-59, Rev. 0

This page intentionally left blank. 


\section{WESTINGHOUSE HANFORD/U.S. DEPARTMENT OF ENERGY \\ ENIRONMENTAL SUMMER SCIENCE CAMP \\ TEACHER APPLICATION}

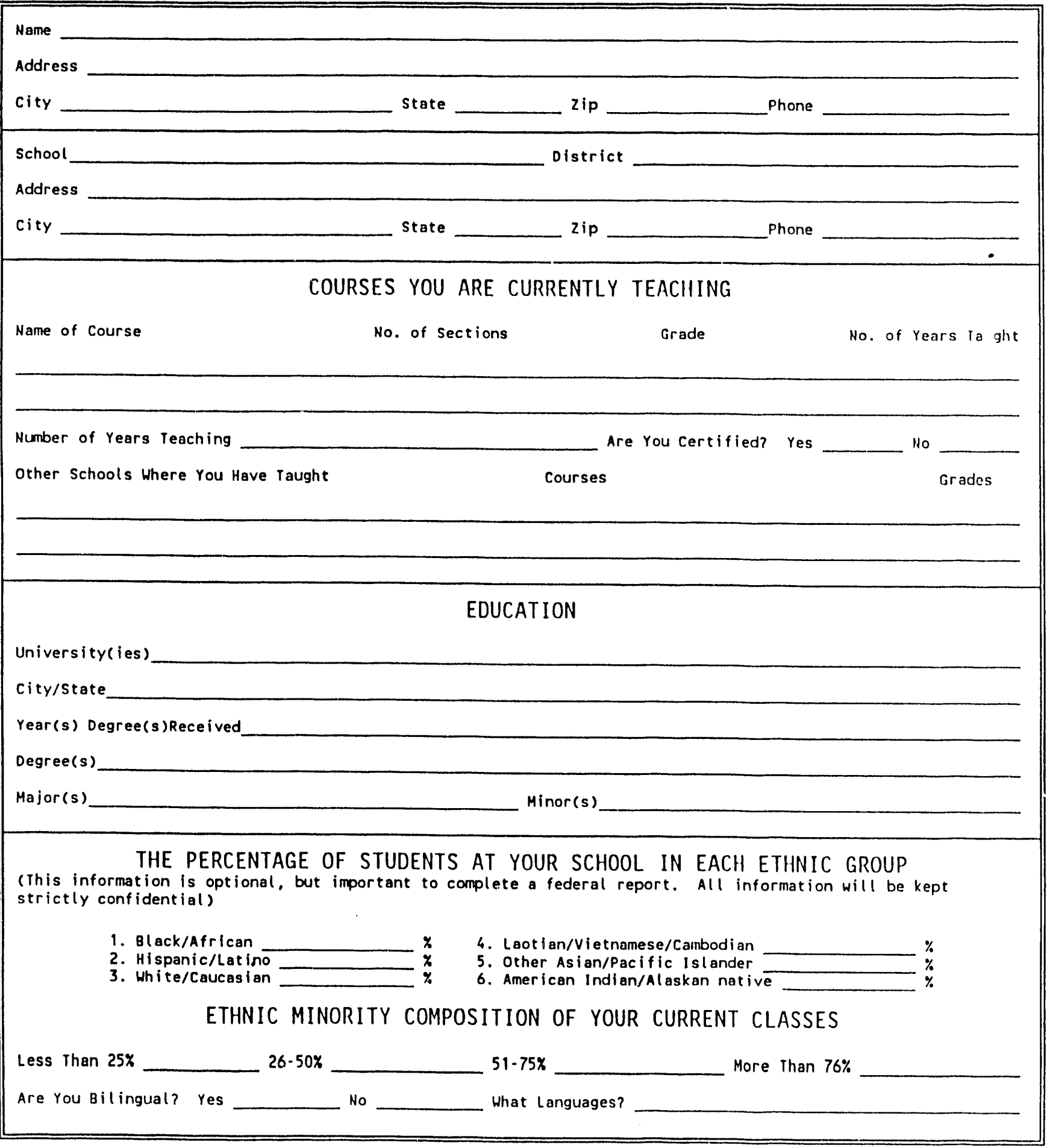



Please list workshops, sumer institutes/seminars or prograns in which you have participated. Indicate year,
length of program, the role you had in the event, and the ages of students impacted.

Indicate professional organizations to which you belong and awards or honors you have recelved.

Describe your present style of teaching, including the extent to which you use experiments, demonstrations, hands-on activities, etc.

Briefly describe experiences or resources that will help you share with other teachers and contribute to the workshop.

What would you like to gain from working with professional scientists and engineers?

I cormit to be available for inservice May 16 and May 30 (8:30 am - 4:30 pm), and both sessions of sumrner camp July 13-17 and July 20-25 (12:30 pm - 4:30 pm.

Applicant Signature:

APPLICATION DEADLINE: MONDAY, MAY 11, 1992 Return completed form to:

Gwen Leth, Education Specialist

Westinghouse Hanford Company

Educational and Internship Performance

P.O. Box 1970, Mail Stop H3-24

Richland, WA 99352-1970

Questions? Call Gwen Leth 376-5252 
WESTINGHOUSE HANFORD/U.S. DEPARTMENT OF ENERGY

ENVIRONMENTAL SUMMER SCIENCE CAMP TEACHER RECOMMENDATION FORM

JULY $13-17$ and $20-24,1992$

COLUMBIA BASIN COLLEGE CAMPUS

NAME OF APPLICANT

SCHOOL

\section{SCHOOL DISTRICT}

1. How long have you known this applicant? Years Months

2. Please rate this teacher as realistically as you can in the areas listed.

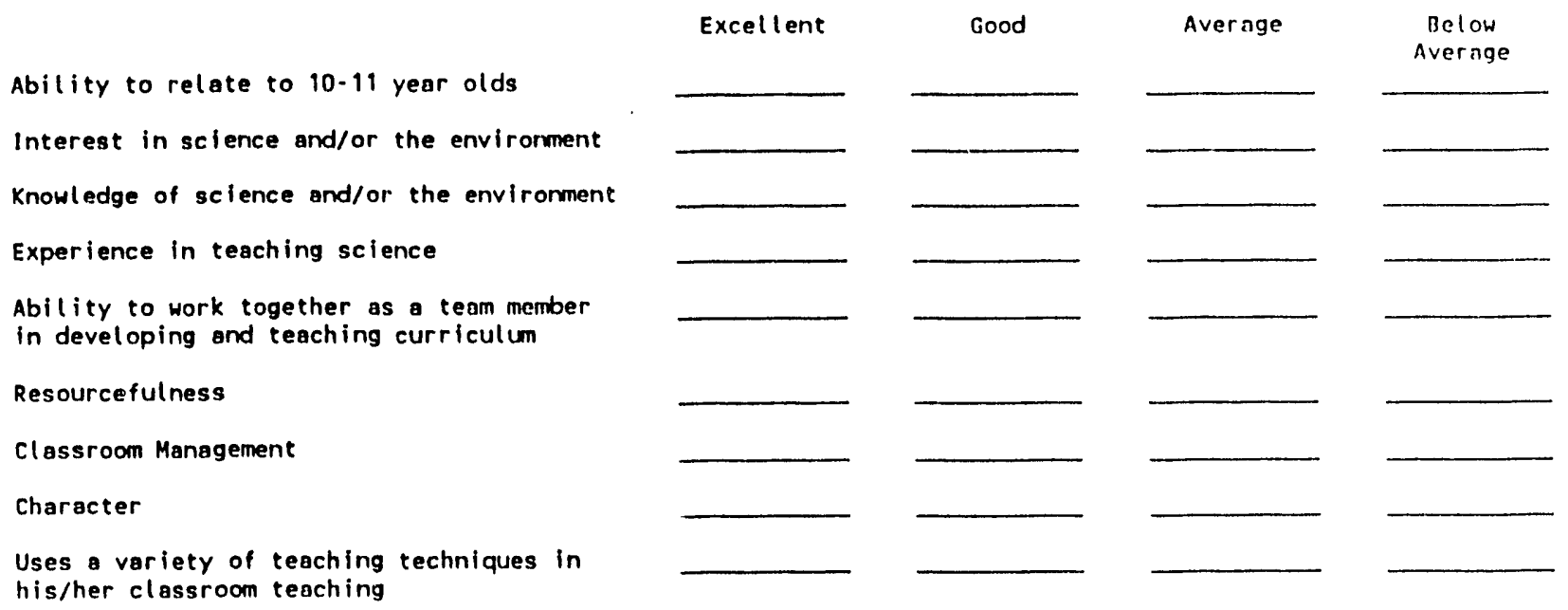

3. Does the applicant have other qualities which would enhance the success of the camp?

4. What are the first few words that come to mind to describe this teacher's classroom teaching style?

Without reservation; I recommend this teacher to participate as an instructor for the Environmental Summer Science Camp. 
DOE/RL-93-59, Rev. 0
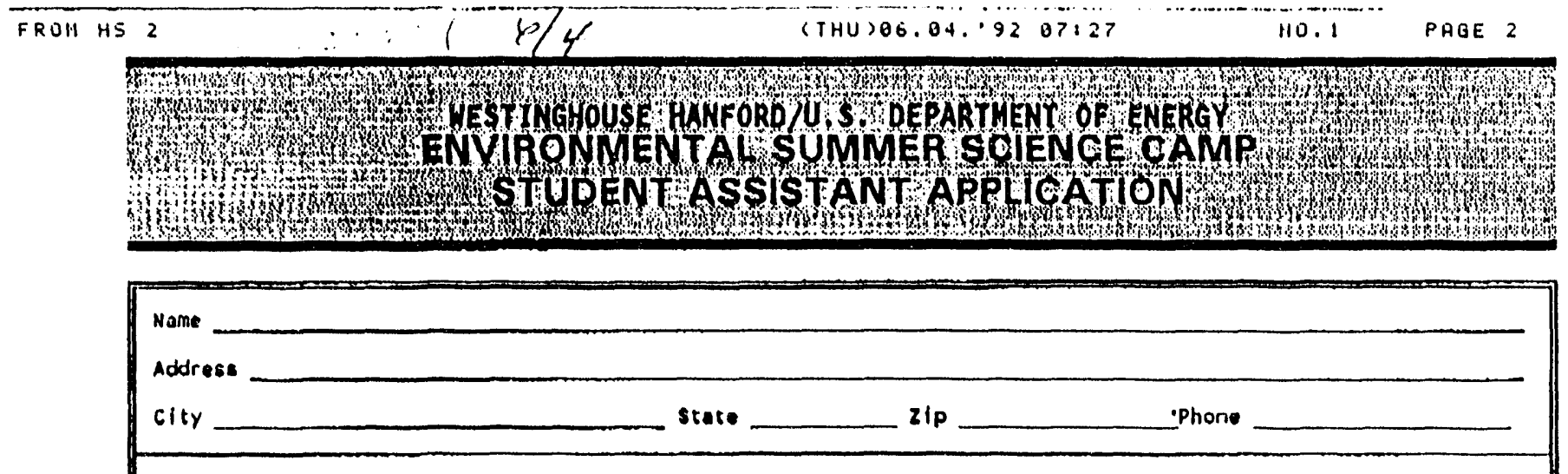

What are your future goals?

Plans for colleo or other post-high school educetion or treining?

Please list any awards or honors you have recelved.

List any school clubs, service organizetions, student govermment, athletle teams, MESA, Upword Bound, etc in which you participate. Include any offices that you hold or have hold.

List non-school activities (employment, church comnunity, etc.)

Liat your spacial interests, hobbles, talents.

On the back of this applleation please describe yourself. Your stotcment should include why you sre interosted in science, your strengths, attitudes end/or ekills explaining how you could contribute.

I conmit to availability for both sessions of the sumer camp; July 13-17 and July 20-25, 12:30-4:30 p.m. Student Applicant signatura

APPLICATION DEADLINE: MONDAY, JUnE 8, 1992

Return coinpleted form to:

Gwen Leth, Education Specialist

Westinghouse Hanford Company

Educational and Internship Performance

P. O. Box 1970, Mail Stop H3.24

Richland, WA 99382-1970

Questions? Call Gwen Leth, 370.5252 
ENVIRONMENTAL SUMMER SCIENCE CAMP STUDENT ASSISTANT RECOMMENDATION FORM

1. How long have you known this applicant? Years Months

2. Please rate this student as realistically as you can in the areas listed.

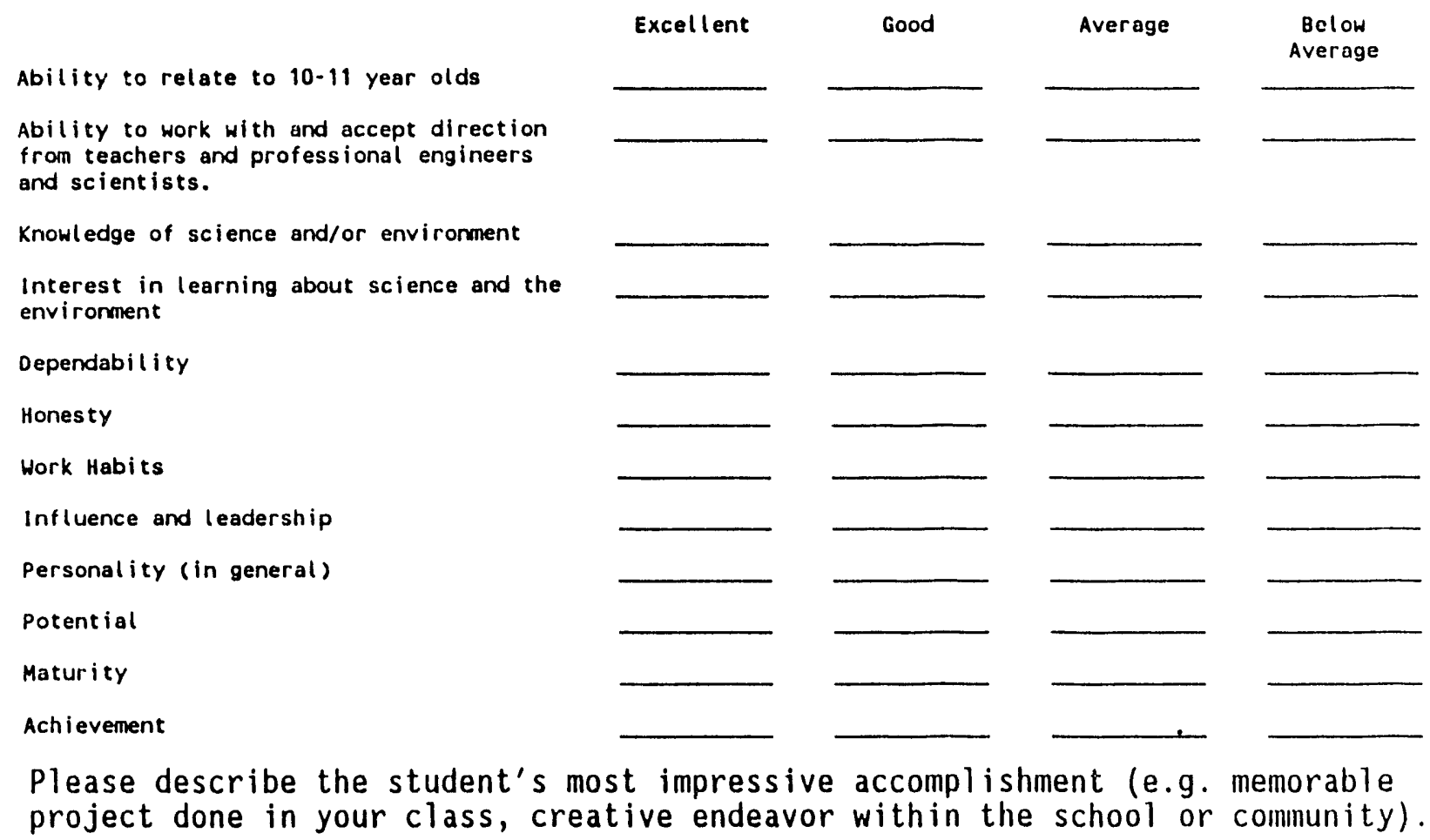

4. Describe student's major strengths and weaknesses.

Without reservation, I recommend this student to participate as an assistant for the Environmental Summer Science Camp. 
DOE/RL-93-59, Rev. 0

STUDENTS RECOMMENDED TO

ATTEND ENVIRONMENTAL SUMMER SCIENCE CAMP

JULY 13-17, 1992 (A) Session

JULY 20-24, 1992 (B) Session

PLEASE NOTE: According to the grant from the U.S. Department of Energy, fifty percent of the students attending the camp must come from under-represented populations with an emphasis on minorities and women. Students must be entering the 6 th grade in September 1992, and have demonstrated an interest in math or science.

TEACHER'S NAME

SCHOOL

Phone:

DISTRICT

NAME OF STUDENTS

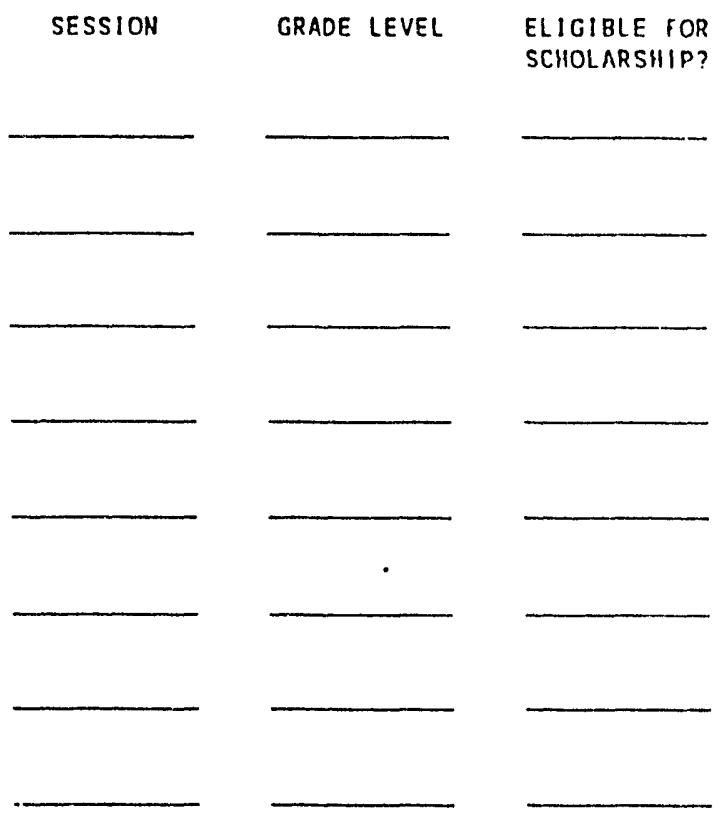

I have talked with the above students regarding their interest in attending the Environmental Science Camp. Each of these students would like to receive additional information regarding the camp. 
DOE /RL-93-59, Rev. 0

APPENDIX C

CAMP SCHEDULE

C -1 
DOE/RL-93-59, Rev. 0

This page intentionally left blank. 
DOE/RL-93-59, Rev. 0

\title{
APPENDIX C \\ CAMP SCHEDULE
}

\section{ENVIRONMENTAL SCIENCE CAMP}

\author{
JULY 13 - 17 AND JULY 20 - 24 \\ Pete Frankovic - Mary Pat Long - Ken Peterson
}

MONDAY

\section{$1: 00-1: 40$}

1. Welcoming Address - George Cox

2. Team Building - Choose a name for the group; brainstorm (nature theme) Room 153

3. PRE TEST

\section{$1: 40-2: 20$}

PLOT STUDY: Outside

1. Measure and layout the $15 \mathrm{M} \times 15 \mathrm{M}$ plot

2. Make observations (general)

half of class at a time - then flip

3. Make an animal survey $\rightarrow$ See chart

- actual animals

- tracks

- what else - bones, casings, feathers

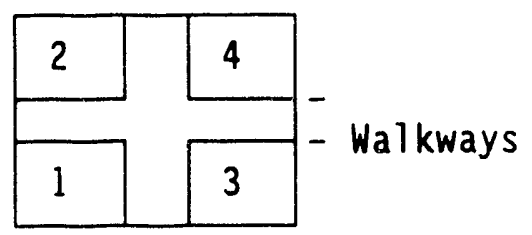

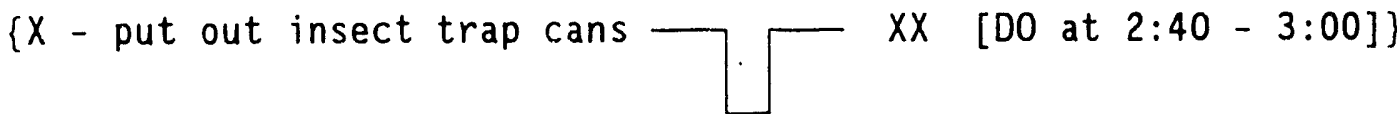

[Enter data into notebook] - Weather Data $-\rightarrow$ See chart
1. time
2. cloud cover
3. five temps
4. humidity
5. wind $\rightarrow$ direction and force 
DOE/RL-93-59, Rev. 0

MONDAY

MATERIALS

$\begin{array}{lll}4 \text { stakes } & \text { notebook } & \text { graph paper } \\ 100 \mathrm{M} \text { string } & \text { colored pencils } & \text { drawing paper } 12 \times 18 \\ \text { flagging } & \text { hand lens } & \text { rulers } \\ 5 \text { thermometers } & \text { cans } & 16 \text { tongue depressors }\end{array}$

2:20-2:40

BREAK TIME

\section{$2: 40-3: 00$}

1. bury insect trap cans

2. color trail

3. materials - hand trowel, cans 3 per plot (12), color trail handout

$3: 00-3: 40$

SPEAKER: Taffy Mercer - The Library, Room 101

3:00 - 3:40

WRAP-UP: Room 153 
DOE/RL-93-59, Rev. 0

TUESDAY

$1: 00-1: 20$

TEAM BUILDING: Room 153 - Sit in a circle

- Rol1 Ca11

$1: 20-2: 00$

PLOT STUDY: Outside

1. make general observations

2. weather data

3. shrub survey

- by species

- location

- height

4. check bug collection

\section{MATERIALS}

- notebook

- thermometers

- yard sticks

- rulers

- fingernail polish

\section{$2: 00-2: 20$}

BREAK TIME

\section{2:20-3:00}

DESIGN A BUTTERFLY: Room 151

\section{MATERIALS}

1. talk about survival and

- scissors

2. choose a spot

3. choose a pattern

4. design a color pattern

- handouts - butterfly patterns

5. cut out and mount in your environment

- colored pencils

- tape

- pipe cleaners

- wire cutters - me

- Butterfly book - reference (see library)

- students may do more than one

6. discuss coloration, mimicry (monarch and viceroy), survival, life span, predators

\section{3:00-3:40}

HIDING BUTTERFLIES AND LOCATING THEM

1. hide the butterflies by groups (of 3 or 4 )

- make group identification on back of each butterfly

2. everyone goes out on the butterfiy search 
DOE/RL-93-59, Rev. 0

\section{TUESDAY}

\section{RULES :}

1. you cannot find any from your group

2. collect your collection and put in your notebook

3. which group found the most - predators survive?

4. each group then goes back to collect any not found

- the group with the most not found WINS!

\section{$3: 40-4: 00$}

WRAP-UP 
DOE/RL-93-59, Rev. 0

WEDNESDAY

$1: 00-1: 20$

TEAM BUILDING: Room 153

1. roll call

2. activity $\rightarrow$ human graph

\section{$1: 20-2: 00$}

HOOKS \& LADDERS: Outside $\rightarrow$ groups $E$ \& $F$ Salmon Life Cycle Game

1. give students some background information

2. handouts on salmon life cycle (see aquatics pack)

\section{$2: 00-3: 00$}

SPEAKER - AMERICAN INDIAN

\section{3:00-3:40}

P.LOT STUDY: Outside

1. make general observations

2. weather observations

3. check bug collection/mark \#2

4. finish shrub survey

(if not done)

\section{MATERIALS}

- notebook

- thermometers

- yard sticks

- rulers

- fingernail polish

\section{3:40-4:00}

WRAP-UP: Room 153

1. general observations

2. give time for journal notes, sharing, art 
DOE/RL-93-59, Rev. 0

THURSDAY

$1: 00-1: 20$

TEAM BUILDING: Room 153

1. roll call

2. activity $\rightarrow$ human graph/color trail

\section{$1: 20-1: 40$}

\section{DEADLY WATERS}

1. discuss pollution and things that get into our water supply

2. graph dots

\section{MATERIALS}

- graph paper

- colored dots

- glue - rubber cement

- art paper $12 \times 18$

- colored pencils

- handout

\section{$1: 40-2: 00$}

DEADLY WATERS - Art

1. study graph and handout to determine what your environment would look like

2. draw and color your environment

3. on the back, describe your environment

\section{$2: 00-2: 40$}

\section{PLOT STUDY}

1. general observations

2. weather observations

3. sketching the plot

4. check bug collection and mark \#3

5. soil survey

- core sample

- water and jar

\section{MATERIALS}

- notebook

- thermometers

- yard sticks

- rulers

- fingernail polish

- jars anc water

- straws

\section{$2: 40-3: 00$}

BREAK TIME 
DOE/RL-93-59, Rev. 0

THURSDAY

$3: 00-3: 40$

SPEAKERS - Astronomy

$3: 40-4: 00$

WRAP-UP

C-9 
FRIDAY

$1: 00-1: 20$

TEAM BUILDING: Room 153

$1: 20-1: 40$

OWL PELLETS

1. dissect ow pellets

2. glue bones to index card

3. give owl info while working

\section{MATERIALS}

- owl pellets

- paper clips

- 5 x 8 index cards

- g1ue

- ziplock bags

- mouse skeleton sheets

\section{$1: 40-2: 00$}

1. continue with ow pellets

2. identify how many mice the owl ate

\section{$2: 00-2: 20$}

BREAK TIME

\section{$2: 20-2: 50$}

JOURNAL SHARING, POETRY, SHORT STORY WRITING

1. dianante (diamond poem)

- acrostic poems

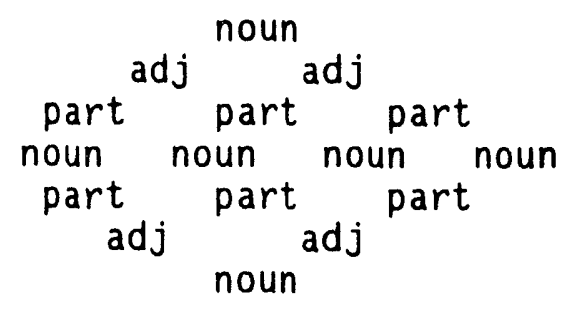

2. word webs

$\begin{array}{lll}E & W & N \\ C & I & A \\ 0 & L & T \\ L & D & U \\ 0 & L & R \\ G & I & E \\ Y & F & \\ & E & \end{array}$

- use environmental words

water 


$$
\text { DOE/RL-93-59, Rev. } 0
$$

FRIDAY

\section{$2: 50-3: 00$}

POST TEST

\section{3:00-4:00}

GRAND FINALE 
DOE/RL-93-59, Rev. 0

\section{TEAM BUILDING}

MONDAY

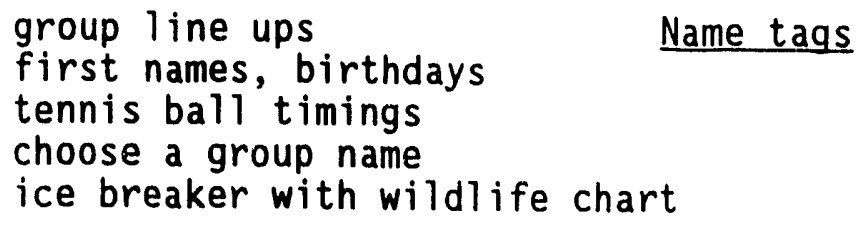

WEDNESDAY human graphs

- shoes

- shirts

- eye color

- foods

- movies

journal writing

IHURSDAY color trail - outside activity journal writing

FRIDAY sit back to back

- list sights

- list sounds

- picture 
DOE/RL-93-59, Rev. 0

APPENDIX D

LESSON PLAN/ACTIVITY SHEETS

D-1 
DOE/RL-93-59, Rev. 0

This page intentionally left blank. 
DOE/RL-93-59, Rev. 0

\section{D.1.0 ENVIRONMENTAL SUMMER CAMP LESSON PLAN}

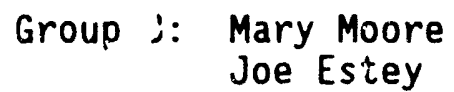

Monday Plot Study

Purpose: To instruct the student in the balance and value of each segment of the local ecosys,tem through hands on research and evaluation including surveillance of plant and biological life, food cycles, botanical categorizations, etc.

Activity: Collect samples of soil for PH, moisture content and mineral analysis. Identify and log all plant and biological life. Set scorpion and bug traps to support the study of animal life.

Tuesday Science Lab

Purpose: To discuss hazardous materials and wastes and their effect on the environment by performing simple elementary lab experiments on common household products. Use hands on field sampling of specially prepared solutions (vinegar, baking soda, salad oils) to demonstrate how science is helping to clean up the environment when unknown or abandoned containers are discovered in a field, landfill, or backyard.

Activity: Perform field sampling using coliwasa and grain samplers in the Group B plot area: Containers of unknown materials $w^{i} 11$ be placed in the area for the kids to hunt down and investigate. The material will be sampled, along with the environmental media (soil) in the immediate area in order to determine if environmental damage has occurred. Household hazardous materials will be 1 isted and discussed with product substitutes described to the students. Simple lab experiments, such as $\mathrm{pH}$ paper testing or acidity color testing with red cabbage juice will be done.

Wednesday "World in Jeopardy" Game

Purpose: Using a modern day TV show format, the students will learn valuable information about the environment, industry, and themselves.

Activity: Students will be divided up into various teams surrounding a large Game Board, similar to the Jeopardy TV show board. Various questions will be asked about recycling. source reduction, pollution, and the 
ecosystem. A "Truth or Dare" option will be given to the students so that if they are unable to answer the question, they can choose a "dare" in order to gain points.

All Week: Recycling Drive

Purpose: To teach students the value of recycling.

Activity: Tote boards will be made up to track the collection of newspaper and aluminum cans. The winning student will be given a special prize at the end of the week long drive. 
DOE/RL-93-59, Rev. 0

\section{D.2.0 ECODRAMA}

\section{INTRODUCTION}

The idea is to teach ecological ideas by acting out the ideas, i.e., multidimensional learning or learning with more than just books, pencils and papers. The concept is not confined to science or conservation, and may be adapted freely. There are no copyrights!

\section{SUGGESTIONS}

Generally there should be no talking. We desire action, not words. Keep it short and pointed - don't drag it out or make it too elaborate, though props are permissible. You do not have to do all the exercises, nor do you have to do them in any particular order. BE CREATIVE! Discussion should follow each exercise.

\section{EXERCISES}

\section{A. Grouping - for want of a more clever term}

All participants stand in a circle and are quietly assigned roles b: the leader. There should be at least three groups (crows, bullfrogs, and mosquitoes, for example). Each participant acts out his/her role as best they can while moving to others acting out a similar role. When all have formed their group, each group demonstrates for the others who try to guess what they are. Sometimes an individual who has no group can be used as a "ringer" to confuse things.

\section{B. Pairs}

Same start as before except this time you assign two of each animal. The pairs must find their partners. Odd number of students may be assigned to another pair or may be used as ringers.

\section{Group Animal}

Two groups (or more) are each allowed to pick an animal (one organism). As a group, they act out the animal for the other group who in turn acts for them. Then the groups switch animals. Don't allow too much time to discuss... encourage action!

\section{Concepts}

Groups act out environmental or other science concepts (you are not limited to the topics listed below):

1. water cycle

2. growth

3. recycling

4. seasons 
DOE/RL-93-59, Rev. 0

5. food chain

6. planets

7. constellations

E. Short Spontaneous Plays.

Groups create short plays with or without dialogue. The plays can be topical or situational. Give them a situation and enjoy the results! 


\section{D.3.0 DEMONSTRATION ACTIVITIES FINDING THE DEW POINT}

\section{FOR YOUR INFORMATION}

Humidity has an effect on the rate at which water evaporates into the air. As well as evaporating, water vapor in the air also condenses (joins together) to form drops, and liquid water "appears" out of the air. One of the conditions that affects both evaporation and condensation is air temperature. If air (containing water vapor) is cooled, there will be a point reached at which the water vapor in the air begins to condense and for a liquid. This air temperature is called the dew point. In the following investigation, your class will discover the dew point of the classroom.

\section{QUESTION}

What is the dew point of the classroom?

\section{TIME}

30 minutes

\section{MATERIALS}

Thermometer

Tin can (soup size) 1 per team

Ice

1 bag

Stirring rod

Paper towel

1 popsicle stick or straw per team

1 - 2 per team

\section{PROCEDURE}

(1) Remove the label from a soup size can. Add water that is at room temperature (or warmer) until the can is half full. Wipe dry the outside of the can with a paper towel. Place the thermometer in the can.

(2) Add a few small pieces of ice while stirring the mixture. Use a stirring rod, not the thermometer, to mix the ice and water.

(3) Other members of your team should carefully observe the outside of the can. After a minute or two, add another piece of ice, stir, and wait. Repeat this process until dew is observed on the outside of the can. At the first signs of moisture, or dew, read the thermometer. Record the water temperature in your notebook.

\section{OTHER POSSIBILITIES}

(1) Compare the results of your investigation with other teams in the room. Did you all use the same temperature of water when your started?

(2) Repeat and determine the dew point of the air outside. What could cause the difference in the date collected indoors and outdoors? 
DOE/RL-93-59, Rev. 0

\section{A FEW SUGGESTED QUESTIONS}

1. What is cheat grass more abundant than other plants?

2. Why are there no trees?

3. Which insects (bees, grasshoppers, beetles, etc.) are the most common?

a. Why do you think there are more of one kind than another?

4. Does the weather (climate) determine the kinds of living things present in this area?

5. Is the soil:
a. acid base
b. sand, clay or loam
c. rich in humus (dead decayed stuff) or living matter
d. is this good soil, or poor soil? Why?

6. Is water readily available? Why or why not?

7. Which animal (spiders, grasshoppers, snakes) is the best consumer of the others?

8. What color are the shrubs? Why is the color important to their survival?

9. Are there any differences in the plant leaf shape, color, twigs?

Other questions may be asked. The important idea at this stage of development is not necessarily right or wrong, but the encouragement of reasoning. 
DOE/RL-93-59, Rev. 0

\section{WEATHER DATA - FOR EACH DAY}

\section{DATE:}

\section{TIME:}

\section{OBSERVE:}

1. Cloud cover:

2. Temperatures:
a. $1 \mathrm{M}$ height air:
b. On the ground (surface):
c. Inside shrub:
d. Inside a burrow:
e. In the shade:

3. Humidity:

4. Wind:
a. Direction:
b. Force: 


\section{DEW WAH DITTY DITTY}

Fill your can about two-thirds full of water.

Observe the starting temperature; record it in the table.

Add ice a little bit at a time. Stir the ice and water mixture slowly until the temperature stops dropping. Then add a little more ice and stir. Record the temperature in degrees celsius every minute in the table.

At some point, moisture will start to form on the outside of the can. Place a " $D$ " in the prediction column by the minute you think dew will start to form (on the outside of the can).

Before you start, fill in the following sentence:

"I predict dew will form (on the outside of the can) at degrees celsius."

\begin{tabular}{||c|c|c|}
\hline PREDICTION & MINUTES & TEMPERATURE \\
\hline \hline & 1 & \\
\hline & 3 & \\
\hline & 4 & \\
\hline & 5 & \\
\hline & 6 & \\
\hline & 7 & \\
\hline & 8 & \\
\hline & 9 & \\
\hline
\end{tabular}


DOE/RL-93-59, Rev. 0

\section{DEMO ONLY - USE FIRE TO HEAT $\mathrm{H}_{2} \mathrm{O}$}

\section{PRODUCTIVITY. How much food energy is there?}

Grasses and other small plants

$$
<-\cdots \text { Roots }
$$

Using scissors, cut all of the grasses and small plants off at ground level. Do this in 5 , $1 D M^{2}$ sites. Put cut plants in plastic bags and seal. Mark your bags with an identifying team name and location.

Plants are gone

Roots $\cdots>$

Take the bags back to the lab.

1. Weigh the bag.

2. Subtract the weight of the plastic bag.

3. Open your bag.

4. Place in an incubator on low heat $\left(37.5^{\circ} \mathrm{C}\right)$.

5. Leave in the incubator for two days.

6. Reweigh the bag.

The dry weight is the number of calories ( $)$ energy in $1 \mathrm{dm}^{2}$.

$1 \mathrm{~g}$ dry weight $=1$ calorie

From this, you can calculate the amount of energy in your plot available to all the consumers (eaters). 
DOE/RL-93-59, Rev. 0

This page intentionally left blank. 
DOE/RL-93-59, Rev. 0

\section{APPENDIX E \\ SURVEY DATA}


DOE/RL-93-59, Rev. 0

This page intentionally left blank. 
DOE/RL-93-59, Rev. 0

APPENDIX E

SURVEY DATA

ENVIRONMENTAL SUMMER SCIENCE CAMP

1. How did your participation in teaching for the ESSC affect your teaching in your classroom this school year 92-93?
a. very little impact
b. some impact
a. 2
b. 3
c. significant impact
c. 5

2. What part of your teaching practices were positively impacted due to your participation in the science camp?
a. increased hands-on science
a. 4 activities
b. more time studying science
c. more time on environmental topics
b. 0
c. 5
- Note: One toacher did not teach science so this question did not pertain

3. Was your understanding of the environmental topics increased because of the camp?
Yes
YES 10
No
NO 0

4. Did you incorporate information about Hanford into your curriculum relating to the environment?
Yes
YES 8
No
NO 2

5. Did you use any of the activities developed for the camp in your classroom?
Some
SOME 4
Many
MANY 4

- Note: Two teachers were not teaching science subjects so the questions did not pertain. 
DOE/RL-93-59, Rev. 0

6. Is your enthusiasm for environmental education as great now as it was during the camp?
Yes
YES 9
No
NO 1

7. Were your students more interested in science this year as a result of your interest generated by your participation in the camp?

Some

No Change

Increased Positively
SOME 7

NO CHANGE 2

INCPEASED POSITIVELY 1

8. Did you consider the camp experience to be an enjoyable one?

$\begin{array}{llr}\text { Yes } & \text { YES } & 10 \\ \text { No } & \text { NO } & 0\end{array}$

COMMENTS BY THOSE SURVEYED:

- Excellent! When is the next one?

- Wildly successful!

- Wish they were doing it again this year.

- Need this camp again.

- Disappointed not have this year. Neat camp! 


\section{ENVIRONMENTAL SUMMER SCIENCE CAMP SURVEY OF STUDENT BEHAVIOR}

The following observations identified changes in the behavior of 105 students (ranging from thira to seventh grade), which came about as a result of their participation in the August, 1992 Environmental Summer Science Camp. Teachers and administrators rasponded to the May, 1993 survey after observing the changes in their students.

1. Student's grade in science improved from the Spring quarter of 92 to Fall quarter of '92?

$\frac{\text { Improved }}{31 \%(33} . \quad \frac{\text { Same }}{34 \%(36)} \quad \frac{\text { No Improvement }}{11 \%(11)} \quad \frac{\text { No Response }}{24 \%(25)}$

2. Student increased his/her selection of science related courses?

Increased $41 \%(43)$ $\frac{\text { No Increase }}{20 \%(21)}$

No Response

3. Student demonstrated greater interest in science during the Fall quarter?

$\frac{\text { Yes }}{10 \%(73)} \quad \frac{\text { No }}{17 \%(18)} \quad \frac{\text { No Response }}{13 \%(14)}$

4. Student deminstrated interest in environmental topics during Fall quarter of ' 92 ?

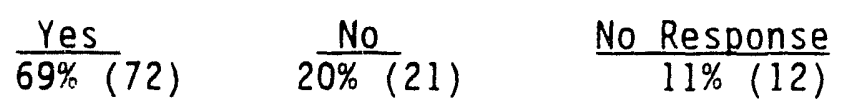

Comments: "wrote to editor of newspaper demanding better environmental treatment"

"our class went environmental crazy"

"more concerned about the earth and cleaning it up"

"did a report on endangered species by chcice"

"initiates projects and involved in experiments"

"doing a project on Greenhouse effect, endangered species"

"knowledge about environmental topics"

"didn't initiate discussion, but added to science discussion"

"especially pollution and extinct animals"

"always participated in contests and discussions"

"very involved in experiments and class projects"

"involved in class projects and experiments"

"enjoyed science, participated in all experiments"

"very active participant in class activities"

"knows a lot about environmental issues"

"very interested in ocean pollution"

"went to KEPR, part in KEDS news, saving the planet"

"normal amount"

"neat kid, so artistic in explaining scientific material" 


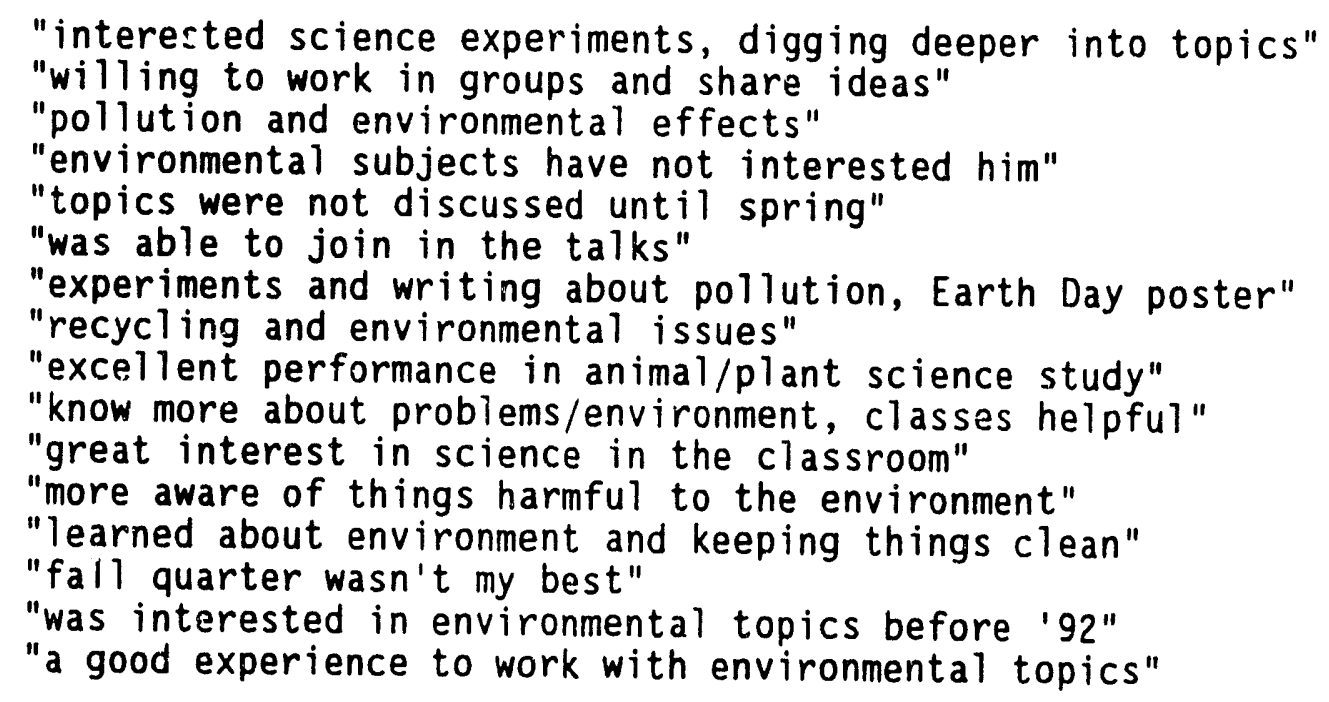

5. Student's attendance in school improved from Spring ' 92 to Fall '92?

$\frac{\text { Improved }}{34 \%(35)} \quad \frac{\text { Same }}{16 \%(17)} \quad \frac{\text { No Improvement }}{20 \%(21)} \quad \frac{\text { No Response }}{30 \%(32)}$
6. Student's interest in school seems to have improved from Spring ' 92 to
Fall ' 92 ?

$\frac{\text { Improved }}{47 \%(49)} \quad \frac{\text { Same }}{6 \%(6)} \quad \frac{\text { No Improvement }}{16 \%(17)} \quad \frac{\text { No Response }}{31 \%(33)}$

Comments: "really enjoyed science camp"

"science classes are required"

"motivation/interest/performance is always high"

"shows a lot of interest in science"

"enrolled in karate, too"

"involved in outside science activity, but not in school"

"good attendance and interest in school"

"demonstrated a strong interest in science" 
DOE/RL-93-59, Rev. 0

\section{APPENDIX $F$}

REPORT OF SURVEY RELATING TO

THE SUMMER SCIENCE CAMP 
DOE/RL-93-59, Rev. 0

This page intentionally left blank.

$F-2$ 
DOE/RL-93-59, Rev. 0

APPENDIX $F$

REPORT OF SURVEY RELATING TO

THE SUMMER SCIENCE CAMP

\author{
Sponsored by the \\ Education and Internship Performance Group \\ of the \\ International Environmental Institute
}

Fà11, 1992

$F-3$ 
DOE/RL-93-59, Rev. 0

TABLE OF CONTENTS

IEI Summer Science Camp

Methodology . . . . . . . . . . . . . . . . . . . . . . . 1

Purpose, Applications and Objectives . . . . . . . . . . . . . . 2

Executive Summary . . . . . . . . . . . . . . . . . . . . 4

Summary of Findings . . . . . . . . . . . . . . . . . . 5

Graphs .. . . . . . . . . . . . . . . . . . . . . 7

Appendices:

F-A. Summer Science Camp Student Survey "Before" . . . . . . . . . 12

F-B. Summer Science Camp Student Survey "After" . . . . . . . . . 18

F-C. Responses to Open-ended Questions on SSC After Survey . . . . 25

F-D. Teachers Survey .. . . . . . . . . . . . . . . . 41

F-E. Non-teachers Survey . . . . . . . . . . . . . . . . . 44

F-F. Parents Survey .. . . . . . . . . . . . . . . 45 
DOE/RL-93-59, Rev. 0

\section{METHODOLOGY}

\section{IEI Summer Science Camp}

A week-long summer science camp was held on two consecutive weeks in July. The first five-day session ran July 13-17, 1992; a repeat second session ran July 20-24. At the beginning of each session, students were asked to complete a short questionnaire about opinions and attitudes relating to the environment and to preference for classes in school.

On Friday, the last day of each session, a second questionnaire was administered. This asked questions identical to the Monday survey, plus questions related to their experiences in the summer camp.

Although both sessions were surveyed, limitations of time, money and manpower made expedient the analysis of only one of the two weeks during which data was gathered. It was desired to evaluate change that occurred in student

attitudes during the camp. To do this, the same group had to be measured both before and after. The second session was chosen because the demographics of gender and race were added to the questionnaire in the second session.

Data from closed-ended questions was compiled and tabulated. Results appear in Appendix F-A. Data from open-ended questions were tabulated, categorized and appear in Appendix F-C. 
$\mathrm{DOE} / \mathrm{RL}-93-59$, Rev. 0

\section{PURPOSE, APPLICATIONS, AND OBJECTIVES

\author{
IEI Summer Science Camp
}

Ju1y 1,1992

\section{Purpose:}

1) To obtain data and information from students to see if the Summer Science Camp (SSC) had a positive influence on interest, awareness, and knowledge of selected environmental sciences. Students' perceptions of the camp and knowledge and attitudes towards environmental subjects taught in the camp will be measured. One goal is to increase the likelihood that students will choose math and science courses for middle and high school electives.

2) To obtain data and information from SSC teachers to see if teaching the program has a positive influence on either technical knowledge or teaching methods (teaming, hands on, 1 ive demonstrations, pupil involvement versus lecture) as a result of working with Hanford engineers.

3) To obtain data and information from parents regarding their perceptions of their children's experiences at SSC. Also measure parents' exposure and attitudes toward science, toward environmental issues, and toward Hanford in order to better understand where the children may be coming from on these matters.

4) To obtain data and information from WHC/BCSR employees to see if the SSC teaching experience was time well spent personally and professionally. Also find out if and how they were able to relate camp activities to careers.

\section{Applications:}

A. Determine the value to DOE of continuing to fund the SSC.

B. If the SSC shows evidence of meaning and value and is deemed to be continued, improve methods, techniques, and materials that teachers use in the SSC.

C. Provide WHC data regarding continued participation in the program.

D. Identify presentations and materials which might continue to be provided to schools on environmental studies and sciences.

Objectives:

1. Measure interest, awareness, knowledge and attitudes towards environmental sciences both before and after the SSC in the areas of soils, birds and animals, environmental $3 \mathrm{R}^{\prime} \mathrm{s}$ (recycle, reuse, reduce), and career opportunities in environmental areas. 
2. Determine what aspects of the SSC students liked best and what were the factors which contributed to these preferences.

3. Determine what aspects of the SSC students liked least and what were the factors which contributed to the dislike.

4. Measure teachers' typical past teaching methods with regard to the frequency of lecture compared with live demonstrations or hands-on student involvement in the learning process.

5. Measure teachers' attitudes towards using techniques which involve students after the SSC.

6. Measure teachers' perceptions of knowledge or new information gained through working with Hanford engineers and scientists.

7. Determine how parents perceived their children's experiences at SSC.

8. Measure parents' attitudes towards science in general, towards specific environmental issues including the $3 \mathrm{R}^{\prime} \mathrm{s}$ of environmental preservation, and towards Hanford.

9. Determine what students, teachers, and employees thought about the program and what might be done to improve it. 


\section{EXECUTIVE SUMMARY}

\section{IEI Summer Science Camp}

Students came away from the Summer Science Camp with a somewhat increased interest in science, improved knowledge and attitudes towards the environment, and a somewhat increased propensity to recjcle, reuse, and reduce in the interest of environmental conservation.

On most measures, there was improvement after the camp. However, in many instances, the improvement was a trend, and did not demonstrate statistical significance. It would be unreasonable to expect a 15-hour long summer camp to achieve a high level of statistical significance in changing attitudes and behavior. The fact it showed a positive trend suggests the activities were "on track."

There was evidence that the experience increased interest in science, although this increase was not statistically significant. As a group, participating students had a high interest in science at the outset. The interest increased somewhat, but the data suggest the camp was "preaching to the choir" in that the camp didn't increase interest in science so much as it attracted those whose interest was already high.

One measure which demonstrated statistical significance was the increased awareness of the fact that there are many jobs available related to the environment.

One significant different between teachers teaching in school and the same teaching in the Summer Science Camp is the amount of time spent lecturing. Teachers said they lectured significantly less in the camp than in school. This may account for some of the enthusiasm students had for the camp over school.

Another interesting point is that the teachers who participated in the SSC overwhelmingly felt that it is more important for a teacher to have a love in working with students more than an excellent grasp of the subject.

Both teachers and employees alike said they learned something new from the Camp experience. Both groups said they would like to participate in another Camp. 
DOE/RL-93-59, Rev. 0

\section{SUMMARY OF FINDINGS}

\section{IEI Summer Science Camp}

1. Student preferences for science as a preferred class in school increased after the camp, compared with before. The increase was small, significant at the .16 level of confidence, short of the .05 level normally used for statistical significance. However, the preference for science increased a little after the camp compared with before.

2. Overwhelmingly, studencs recognized that the study of the environment is a science, both before (90\%) and after (95\%). The increase was not statistically significant. Speculation: the large percentage of students that associated environment with science may have been due, in part, to the activity being billed as "the Environmental Summer Science Camp."

For comparative purposes, students were asked whether other topics, in addition to "environment," should be considered a science. There was a statistically significant increase in students who thought of agriculture as a science after, compared with before. This was the only topic which demonstrated statistical significance.

3. Students' awareness of what the environment is increased after the camp. The increase demonstrated statistical significance. Students were given a choice of seven items and were asked, "What is an example of the environment?" All the items related to the environment. The correct answer was "all of the above." Nine percent more correctly answered the question after the camp than before $(72 \%$ to $81 \%)$. This is significant at the .05 level of confidence.

4. There was a statistically significant increase in the number of students who became aware that Hanford was the nation's largest environmental cleanup site. The 16-point jump (22\%, before; $38 \%$ after) was significant beyond the .01 level of confidence.

5. Attitudes and knowledge of the environment were increased after the camp compared with before. All measures increased somewhat, but only the awareness of job opportunities in environmental areas demonstrated statistical significance (<.03 level of confidence) in improvement.

6. Purported behaviors regarding recycling, reducing and reusing were improved after the camp. It must be recognized that any such improvement inay well reflect a bias of what is socially appropriate and what is not. The survey measured only what the students said they did, not what their actual behavior is. However, if awareness and attitudes toward recycling, reducing and reusing are improved, it seems reasonable over time to expect behavior to also improve.

7. Students overwhelmingly liked the camp. Over half (52\%) gave the camp the highest rating possible, and $86 \%$ indicated they liked it at least a 1ittle. Nearly three out of four said they were willing to attend 
another camp. Some $90 \%$ would recommend friends attend the camp, and over half $(55 \%)$ of those responding would encourage friends to go.

8. The unit on birds was the most popular in the second session. The unit on soils was the least liked activity in terms of numbers, but a number of students favored it highly. Dissecting owl pellets interested many, although a few didn't like it.

9. Students favored hands-on activities that required their involvement. They found lectures boring, uninteresting. Students wanted the activities to be less like school, especially minimizing lectures.

10. Teachers said they lectured considerably less in the SSC than in the regular school classroom. This was quite statistically significant beyond the .001 level of confidence.

11. Both teachers (67\%) and employees (97\%) who participated in the camp said they gained new knowledge and information. All members of both groups who responded to the survey said they would either "definitely" want to participate in another SSC ( $80 \%$ for both teachers and employees) or would "probably" want to participate.

12. Four out of five teachers who responded to the survey said they believed it was more important for a teacher to have a love in working with students than for a teacher to have an excellent grasp of subject matter. such a finding might be useful in the future in screening teachers as possible participants. 
DOE/RL-93-59, Rev. 0

\section{INSERT FOR THREE GRAPHS}

1. Preferences for school subjects

2. Change regarding attitudes and knowledge of the environment

3. Change regarding purported behavior of recycling, reducing and reusing 
DOE/RL-93-59, Rev. 0

\section{APPENDIX F-A}

\section{SSC Student Survey B}

July 20, 1992

Here are a few questions on which we would like your opinion. Your answers won't be graded. In fact, we don't even want you to put your name on the paper. Some questions ask about classes you might prefer. Other questions ask for your opinions. And still others ask what you think about certain things or what you do. Indicate your answer by circling the appropriate number. Please try to answer all the questions. And remember, you can't give a bad answer. We want to know what you think about each question.

Below is a list of six subjects often taught in schools. Please look at all six on the list. If you were required to take just one of the six, but were able to choose which one you want, what would you take? Please circle the number "1" next to the subject which is your first choice. Then if you were required to take just two subjects, what would be your second choice? Please circle the number " 2 " next to the subject. In the same way, please indicate your third, fourth, fifth and sixth choices by circling the appropriate number next to each choice.

Q1. History

$$
\begin{array}{ll}
1- & \text { First choice } \\
2- & \text { Second choice } \\
3- & \text { Third choice } \\
4- & \text { Fourth choice } \\
5- & \text { Fifth choice } \\
6 \text { - } & \text { Sixth choice }
\end{array}
$$

\begin{tabular}{rr}
14 & $8 \%$ \\
21 & $12 \%$ \\
30 & $16 \%$ \\
38 & $21 \%$ \\
38 & $21 \%$ \\
41 & $22 \%$ \\
\hline 182 &
\end{tabular}

Q2. Reading

$$
\begin{aligned}
& 1 \text { - First choice } \\
& 2 \text { - Second choice } \\
& 3 \text { - Third choice } \\
& 4 \text { - Fourth choice } \\
& 5 \text { - Fifth choice } \\
& 6 \text { - Sixth choice }
\end{aligned}
$$

$\begin{array}{rr}21 & 11 \% \\ 21 & 11 \% \\ 39 & 21 \% \\ 42 & 23 \% \\ 34 & 18 \% \\ 27 & 15 \%\end{array}$

Q3. Science

$$
\begin{array}{ll}
1 \text { - } & \text { First choice } \\
2- & \text { Second choice } \\
3- & \text { Third choice } \\
4- & \text { Fourth choice } \\
5- & \text { Fifth choice } \\
6 \text { - } & \text { Sixth choice }
\end{array}
$$

\begin{tabular}{lr}
51 & $28 \%$ \\
56 & $31 \%$ \\
30 & $16 \%$ \\
21 & $11 \%$ \\
15 & $8 \%$ \\
10 & $5 \%$ \\
\hline 183 &
\end{tabular}


Q4. Writing

$\begin{array}{ll}1 \text { - } & \text { First choice } \\ 2 \text { - } & \text { Second choice } \\ 3 \text { - } & \text { Third choice } \\ 4 \text { - } & \text { Fourth choice } \\ 5 \text { - } & \text { Fifth choice } \\ 6 \text { - } & \text { Sixith choice }\end{array}$

\begin{tabular}{rr}
11 & $6 \%$ \\
26 & $14 \%$ \\
43 & $19 \%$ \\
33 & $18 \%$ \\
40 & $22 \%$ \\
36 & $20 \%$ \\
\hline 180 &
\end{tabular}

Q5. Arithmetic/Math

$\begin{array}{ll}1 \text { - } & \text { First choice } \\ 2 \text { - } & \text { Second choice } \\ 3 \text { - } & \text { Third choice } \\ 4 \text { - } & \text { Fourth choice } \\ 5 \text { - } & \text { Fifth choice } \\ 6 \text { - } & \text { Sixth choice }\end{array}$

\begin{tabular}{ll}
29 & $16 \%$ \\
33 & $18 \%$ \\
22 & $12 \%$ \\
29 & $16 \%$ \\
37 & $20 \%$ \\
34 & $19 \%$ \\
\hline 181 &
\end{tabular}

Q6. P.E.

1 - First choice
2 - Second choice
3 - Third choi e
4 - Fourth ch ce
5 - Fifth choice
6 - Sixth choice

\begin{tabular}{rr}
64 & $35 \%$ \\
31 & $17 \%$ \\
25 & $14 \%$ \\
17 & $9 \%$ \\
18 & $10 \%$ \\
29 & $16 \%$ \\
\hline 184 &
\end{tabular}

Science means "to know" about something by looking at it and studying it. Some things are considered cience such as biology, chemistry, physics. Other things are usually not considered science such as literature, history, or a language. Please look at the list below. If you believe the topic is an aspect of science, circle "l" for yes, it is science. If you believe the topic is not science, circle "2" for no, it is NOT science. If you are not sure, please circle "3".

Q7. Agriculture

$$
\begin{aligned}
& 1 \text { - Yes, it's science } \\
& 2 \text { - No, it's not science } \\
& 3 \text { - Don't know }
\end{aligned}
$$

Q8. Sculpturing

$$
\begin{aligned}
& 1 \text { - Yes, it's science } \\
& 2 \text { - No, it's not science } \\
& 3 \text { - Don't know }
\end{aligned}
$$


Q9. Environment

$$
\begin{aligned}
& 1 \text { - Yes, it's ciience } \\
& 2 \text { - No, it's not science } \\
& 3 \text { - Don't know }
\end{aligned}
$$

Q10. Traffic safety

$$
\begin{aligned}
& 1 \text { - Yes, it's science } \\
& 2 \text { - No, it's not science } \\
& 3 \text { - Don't know }
\end{aligned}
$$

Q11. Computers

$$
\begin{aligned}
& 1 \text { - Yes, it's science } \\
& 2 \text { - No, it's not science } \\
& 3 \text { - Don't know } \\
& 4 \text { - Other }
\end{aligned}
$$

\begin{tabular}{rr}
130 & $71 \%$ \\
25 & $14 \%$ \\
21 & $11 \%$ \\
8 & $4 \%$ \\
\hline
\end{tabular}

Q12. Circle the one number below which is the best answer to the question, "What is an example of the environment?".

$$
\begin{aligned}
& 1 \text { - Desert } \\
& 2-\text { Your backyard } \\
& 3 \text { - Mountains } \\
& 4 \text { - Oceans } \\
& 5 \text { - Air we breathe } \\
& 6 \text { - Water we drink } \\
& 7 \text { - Weather } \\
& 8 \text { - All of the above } \\
& 9 \text { - None of the above }
\end{aligned}
$$

$\begin{array}{rr}10 & 5 \% \\ 6 & 3 \% \\ 10 & 5 \% \\ 0 & -- \\ 12 & 7 \% \\ 4 & 2 \% \\ 9 & 5 \% \\ 132 & 72 \% \\ \frac{1}{184} & <1 \%\end{array}$

Q13. Which one of the following do you believe might be the nation's largest environmental site that is undergoing environmental cleanup?

$\begin{array}{lrr}1 \text { - Alaska Oil Spill } & 96 & 53 \% \\ 2 \text { - Grand Canyon in Arizona } & 10 & 6 \% \\ 3 \text { - Hanford in Washington } & 39 & 22 \% \\ 4 \text { - Gulf of Mexico along Texas coast } & 8 & 4 \% \\ 5 \text { - Yellowstone National Park } & 16 & 9 \% \\ 6 \text { - None of the dbove } & \frac{11}{180} & 6 \%\end{array}$

Please read each statement and indicate whether you believe the statement is true, false or that you are not sure (don't know).

Q14. There isn't much just one person can do to protect the environment.

$\begin{array}{lrr}1 \text { - True } & 27 & 15 \% \\ 2 \text { - False } & 144 & 79 \% \\ 3 \text { - Don't know } & \frac{12}{184} & 6 \%\end{array}$


Q15. People can become very $i 11$ because of the environment.
1 - True
142
$78 \%$
2 - False
3 - Don't know
$20 \quad 11 \%$
$\frac{21}{183} \quad 11 \%$

Q16. Although there are a few, there really aren't very many job opportunities in environmental areas.
1 - True
28
$15 \%$
2 - False
3 - Don't know
102
$29 \%$
$\frac{54}{184}$
$29 \%$

Q17. Environmental studies apply primarily to large groups of people, not so much to individuals.
1 - True
57
$\begin{array}{rr}67 & 37 \% \\ \frac{59}{183} & 32 \%\end{array}$
2 - Faise
3 - Don't know

Q18. The actions of a student in middle school can help or hurt the environment just as much as the actions of an adult.
1 - True
2- False
147
$80 \%$
3 - Don't know
$20 \quad 11 \%$
$\frac{16}{183}$
$9 \%$

Below is a list of things that some people do, but others choose not to do. Please look at each item and indicate whether this is something your family usually does, sometimes does, or generally does not do. If you're not doing something, but your family has discussed doing it, please indicate that.

Q19. Save soft drink or other aluminum cans for recycling.

$$
\begin{aligned}
& 1 \text { - Usually do } \\
& 2 \text { - Sometimes } \\
& 3 \text { - Rarely } \\
& 4 \text { - Talked about }
\end{aligned}
$$

\begin{tabular}{rr}
125 & $68 \%$ \\
32 & $18 \%$ \\
13 & $7 \%$ \\
13 & $7 \%$ \\
\hline 183 &
\end{tabular}

Q20. Save plastic milk or pop bottles for recycling.

$$
\begin{aligned}
& 1 \text { - Usually do } \\
& 2 \text { - Sometimes } \\
& 3 \text { - Rarely } \\
& 4 \text { - Talked about }
\end{aligned}
$$

\begin{tabular}{rr}
63 & $35 \%$ \\
37 & $20 \%$ \\
53 & $29 \%$ \\
29 & $16 \%$ \\
\hline 182 &
\end{tabular}


Q21. Save glass jars and bottles for recycling.

1 - Usually do

2 - Sometimes

3 - Rarely

4 - Talked about

\begin{tabular}{rr}
73 & $39 \%$ \\
31 & $17 \%$ \\
50 & $27 \%$ \\
29 & $16 \%$ \\
\hline 183 &
\end{tabular}

Q22. Turn off unneeded lights and appliances so as not to needlessly use electricity.

1 - Usualiy do

2 - Sometimes

3 - Rarely

4 - Talked about

\begin{tabular}{rr}
106 & $58 \%$ \\
59 & $32 \%$ \\
10 & $5 \%$ \\
8 & $4 \%$ \\
\hline 183 &
\end{tabular}

Q23. Carry a litter bag in your family vehicle in which to dispose of trash.

1 - Usually do

85

2 - Sometimes

3 - Rarely

4 - Talked about

\begin{tabular}{rr}
85 & $47 \%$ \\
38 & $21 \%$ \\
42 & $23 \%$ \\
17 & $9 \%$ \\
\hline 182 &
\end{tabular}

Q24. Wash and reuse plastic utensils rather than to toss out when used.

$$
\begin{aligned}
& 1 \text { - Usually do } \\
& 2 \text { - Sometimes } \\
& 3 \text { - Rarely } \\
& 4 \text { - Talked about }
\end{aligned}
$$

\begin{tabular}{ll}
73 & $40 \%$ \\
53 & $29 \%$ \\
37 & $20 \%$ \\
20 & $11 \%$ \\
\hline
\end{tabular}

And now we need a little information about you.

$40 \%$

$20 \%$

$11 \%$

Q25. Your age

$$
\begin{aligned}
& 1-10 \\
& 2-11 \\
& 3-12 \\
& 4-13 \\
& 5-14
\end{aligned}
$$

\begin{tabular}{rr}
18 &.$\quad 10 \%$ \\
73 & $41 \%$ \\
62 & $35 \%$ \\
25 & $14 \%$ \\
1 & $<1 \%$ \\
\hline 179 &
\end{tabular}

Q26. Your sex

$$
\begin{aligned}
& M \text { - Male } \\
& F \text { - Female }
\end{aligned}
$$


DOE/RL-93-59, Rev. 0

Q27. Your race
C - Caucasian
B - Black
H - Hispanic
A - Asian
I - Indian (American)
0 - Other

\begin{tabular}{rl}
110 & $71 \%$ \\
7 & $5 \%$ \\
28 & $18 \%$ \\
5 & $3 \%$ \\
4 & $3 \%$ \\
1 & $<1 \%$ \\
\hline 155 &
\end{tabular}

Q28. Grade in school that you will be going into in the fall
$1-5$ th
2 - 6th
17
$10 \%$
$3-7$ th
89
$50 \%$
4 - 8th
66
$37 \%$
$\frac{6}{178}$

Q29. What is your favorite subject in school?

1 - Mathematics
2 - Science
3 - Physical Education
$4-$ Reading
$5-$ Art
6 - History
7 - Writing
8 - Spelling
9 - Other

$\begin{array}{rr}48 & 27 \% \\ 47 & 26 \% \\ 30 & 17 \% \\ 15 & 8 \% \\ 8 & 4 \% \\ 6 & 3 \% \\ 5 & 3 \% \\ 5 & 3 \% \\ 17 & 9 \% \\ 181 & \end{array}$

Q30. What school did you attend this past spring?

The data to this question is better obtained through registration records. This is also true with age and grade in school. 


\section{APPENDIX F-B}

\section{SSC Student Survey A}

\section{July 24, 1992}

Once again, we want to ask your opinion on a number of questions. The first part of this survey may look familiar. It asks the same questions that were asked at the first of the week. Again, as before, you can't give a bad answer. We're interested in learning if any of your opinions have changed during the past week. The latter part of this survey asks for your opinions and thoughts on the Science Camp. Tell us how you really feel about the camp and let us know what we might do to make it better.

Below is a list of six subjects often taught in schools. Please look at all six on the list. If you were required to take just one of the six, but were able to choose which one you want, what would you take? Please circle the number " 1 " next to the subject which is your first choice. Then if you were required to take just two subjects, what would be your second choice? Please circle the number "2" next to the subject. In the same way, please indicate your third, fourth, fifth and sixth choices by circling the appropriate number next to each choice.

Q1. History

$\begin{array}{ll}1 \text { - } & \text { First choice } \\ 2 \text { - } & \text { Second choice } \\ 3 \text { - } & \text { Third choice } \\ 4 \text { - } & \text { Fourth choice } \\ 5 \text { - } & \text { Fifth choice } \\ 6 \text { - Sixth choice }\end{array}$

Q2. Reading

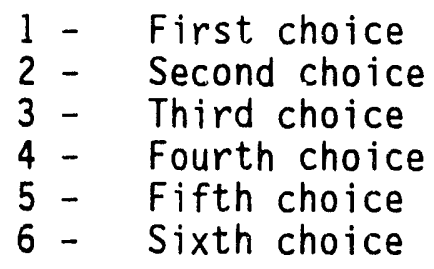

\begin{tabular}{ll}
20 & $13 \%$ \\
17 & $11 \%$ \\
33 & $22 \%$ \\
33 & $22 \%$ \\
25 & $17 \%$ \\
23 & $15 \%$ \\
\hline 151 &
\end{tabular}

Q3. Science

1 - First choice

2 - Second choice

3 - Third choice

4 - Fourth choice

5 - Fifth choice

6 - Sixth choice

\begin{tabular}{rr}
45 & $30 \%$ \\
43 & $28 \%$ \\
29 & $19 \%$ \\
19 & $13 \%$ \\
9 & $6 \%$ \\
6 & $4 \%$ \\
\hline 151 &
\end{tabular}


Q4. Writing

$$
\begin{array}{ll}
1 \text { - } & \text { First choice } \\
2- & \text { Second choice } \\
3- & \text { Third choice } \\
4- & \text { Fourth choice } \\
5 \text { - } & \text { Fifth choice } \\
6 \text { - } & \text { Sixth choice }
\end{array}
$$

Q5. Arithmetic/Math

$$
\begin{array}{ll}
1 \text { - } & \text { First choice } \\
2 \text { - } & \text { Second choice } \\
3 \text { - } & \text { Third choice } \\
4 \text { - } & \text { Fourth choice } \\
5 \text { - } & \text { Fifth choice } \\
6 \text { - } & \text { Sixth choice }
\end{array}
$$

\begin{tabular}{rr}
27 & $18 \%$ \\
34 & $24 \%$ \\
12 & $8 \%$ \\
15 & $10 \%$ \\
24 & $16 \%$ \\
37 & $24 \%$ \\
\hline 149 &
\end{tabular}

Q6. P.E.

$$
\begin{array}{ll}
1 \text { - } & \text { First choice } \\
2- & \text { Second choice } \\
3- & \text { Third choice } \\
4- & \text { Fourth choice } \\
5- & \text { Fifth choice } \\
6 \text { - } & \text { Sixth choice }
\end{array}
$$

\begin{tabular}{ll}
45 & $30 \%$ \\
27 & $18 \%$ \\
23 & $15 \%$ \\
17 & $11 \%$ \\
19 & $13 \%$ \\
20 & $13 \%$ \\
\hline 151 &
\end{tabular}

Science means "to know" about something by looking at it and studying it. Some things are considered science such as biology, chemistry, or physics. other things are usualiy not considered science such as literature, history, or a language. Please look at the list below. If you believe the topic is an aspect of science, circle "1" for yes, it is science. If you believe the topic is not science, circle "2" for no, it is NOT science. If you are not sure, please circle "3".

Q7. Agriculture

$$
\begin{aligned}
& 1 \text { - Yes, it's science } \\
& 2 \text { - No, t's not science } \\
& 3 \text { - Don't know }
\end{aligned}
$$

\begin{tabular}{rr}
115 & $75 \%$ \\
26 & $17 \%$ \\
12 & $9 \%$ \\
\hline 153 &
\end{tabular}

Q8. Sculpturing

$\begin{array}{lrr}1-\text { Yes, it's science } & 28 & 19 \% \\ 2-\text { No, it's not science } & 105 & 70 \% \\ 3-\text { Don't know } & \frac{18}{151} & 12 \%\end{array}$


Q9. Environment

1 - Yes, it's science

2 - No, it's not science

3 - Don't know

Q10. Traffic safety

1 - Yes, it's science
2 - No, it's not science
3 - Don't know

$16 \quad 11 \%$

$119-79 \%$

Q11. Computers

1 - Yes, it's science

$145 \quad 95 \%$

$4 \quad 3 \%$

$\frac{3}{152}$

$2 \%$

2 - No, it's not science

3 - Don't know

\begin{tabular}{rr}
112 & $74 \%$ \\
23 & $15 \%$ \\
17 & $11 \%$ \\
\hline 152 &
\end{tabular}

Q12. Circle the one number below which is the best answer to the question, "What is an example of the environment?".

1 - Desert

2 - Your backyard

3 - Mountains

4 - Oceans

5 - Air we breathe

6 - Water we drink

7 - Weather

8 - All of the above

9 - None of the above

$\begin{array}{rr}1 & <1 \% \\ 4 & 3 \% \\ 7 & 5 \% \\ 1 & <1 \% \\ 11 & 7 \% \\ 0 & --- \\ 3 & 2 \% \\ 123 & 81 \% \\ \frac{1}{151} & <1 \%\end{array}$

Q13. Which one of the following do you believe might be the nation's largest environmental site that is undergoing environmental cleanup?

$\begin{array}{lrr}1 \text { - Bad Lands in South Dakota } & 6 & 4 \% \\ 2 \text { - Grand Canyon in Arizona } & 5 & 3 \% \\ 3 \text { - Hanford in Washington } & 57 & 38 \% \\ 4 \text { - Gulf of Mexico along Texas coast } & 20 & 13 \% \\ 5 \text { - Yellowstone National Park } & 23 & 15 \% \\ 6 \text { - None of the above } & \frac{39}{150} & 26 \%\end{array}$

Below are a series of statements, some of which people say are true, some, people say are false, and some, people say they don't know whether the statement is true or false. Please read each statement and indicate whether you believe the statement is true, false or that you are not sure (don't know).

Q14. There isn't much just one person can do to protect the environment.

$$
\begin{aligned}
& 1 \text { - True } \\
& 2 \text { - False } \\
& 3 \text { - Don't know }
\end{aligned}
$$

\begin{tabular}{rr}
25 & $16 \%$ \\
126 & $82 \%$ \\
3 & $2 \%$ \\
\hline 154 &
\end{tabular}


Q15. People can become very $i 11$ because of the environment.

$\begin{array}{lrr}1 \text { - True } & 129 & 84 \% \\ 2 \text { - False } & 16 & 10 \% \\ 3 \text { - Don't know } & \frac{9}{154} & 6 \%\end{array}$

Q16. A1though there are a few, there really aren't very many job opportunities in environmental areas.
1 - True
14
$10 \%$
2 - False
97
$67 \%$
3 - Don't know
$\frac{33}{144}$
$23 \%$

Q17. Environmental studies apply primarily to large groups of people, not so much to individuals.
1 - True
$51 \quad 33 \%$
2 - False
3 - Don't know

$68 \quad 44 \%$
$\frac{35}{154} \quad 23 \%$

Q18. The actions of a student in middle school can help or hurt the environment just as much as the actions of an adult.
1 - True
131
$85 \%$
2 - False
3 - Don't know

$\begin{array}{rr}15 & 10 \% \\ \frac{8}{154} & 5 \%\end{array}$

Below is a list of things that some people do, but others choose not to do. Please look at each item and indicate whether this is something your family usually does, sometimes does, or generally does not do. If you're not doing something, but your family has discussed doing it, please indicate that.

Q19. Save soft drink or other aluminum cans for recycling.

$\begin{array}{lrr}1 \text { - Usually do } & 111 & 74 \% \\ 2 \text { - Sometimes } & 21 & 14 \% \\ 3 \text { - Rarely } & 5 & 3 \% \\ 4 \text { - Talked about } & \frac{12}{149} & 8 \% \\ \text { - } & \end{array}$

Q20. Save plastic milk or pop bottles for recycling.

1 - Usually do

2 - Sometimes

\begin{tabular}{rr}
55 & $37 \%$ \\
31 & $21 \%$ \\
39 & $26 \%$ \\
25 & $17 \%$ \\
\hline 150 &
\end{tabular}

4 - Talked about

$26 \%$

$17 \%$ 
Q21. Save glass jars and bottles for recycling.

$\begin{array}{lrl}1 \text { - Usually do } & 56 & 37 \% \\ 2 \text { - Sometimes } & 35 & 23 \% \\ 3 \text { - Rarely } & 40 & 26 \% \\ 4 \text { - Talked about } & \frac{20}{151} & 13 \%\end{array}$

Q22. Turn off unneeded lights and appliances so as not to needlessly use electricity.
1 - Usually do
2 - Sometimes
$\begin{array}{ll}95 & 63 \% \\ 46 & 30 \%\end{array}$
3 - Rarely
4 - Talked about

$\begin{array}{rr}10 & 7 \% \\ 0 & --\end{array}$

Q23. Carry a litter bag in your family vehicle in which to dispnse of trash.

$$
\begin{aligned}
& 1 \text { - Usually do } \\
& 2 \text { - Sometimes } \\
& 3 \text { - Rarely } \\
& 4 \text { - Talked about }
\end{aligned}
$$

$\begin{array}{rr}82 & 55 \% \\ 32 & 12 \% \\ 27 & 18 \% \\ \frac{9}{150} & 6 \%\end{array}$

Q24. Wash and reuse plastic utensils rather than to toss out when used.
1 - Usually do
2 - Sometimes
3 - Rarely
4 - Talked about

\begin{tabular}{rr}
67 & $46 \%$ \\
44 & $30 \%$ \\
24 & $16 \%$ \\
11 & $8 \%$ \\
\hline 146 &
\end{tabular}

Now we would like to ask you some questions about the Summer Science Camp. While your answers will be combined with answers of others who participated, we are very interested in what You have to say. Please say what ever you feel is appropriate.

Q25. On a scale of 1 to 7 , where 1 means you disliked summer camp very much and 7 means you liked the camp very much, please indicate how you feel about the Science Summer Camp.

$\begin{array}{rrr}1- & & \\ 2- & 5 & 3 \% \\ 3- & 1 & <1 \% \\ 4- & 6 & 4 \% \\ 5- & 9 & 6 \% \\ 6- & 17 & 11 \% \\ 7-\text { Like camp very much } & 34 & 23 \% \\ & \frac{77}{149} & 52 \%\end{array}$


Q26. If you had the opportunity to attend another camp, similar to this but with some new material, would you participate?
1 - Yes, definitely
59
2 - Yes, probably
$40 \%$
3 - Not sure I'd
49
4 - Probably not
5 - Definitely not
$33 \%$
$22 \%$
$5 \%$
$\frac{1}{149}$
$<1 \%$

Q27. Of a11 the activities throughout the week, which one did you like the best?
1 - Unit on soils
2 - Unit on birds
3 - Unit involving Indians
4 - Other (specify)

$\begin{array}{rr}31 & 21 \% \\ 87 & 58 \% \\ 0 & -- \\ \frac{33}{151} & 22 \%\end{array}$

Q28. What about your favorite unit did you like the most?

Q29. Of all the activities throughout the week, which one did you like the least?

$\begin{array}{lrr}1-\text { Unit on soils } & 58 & 39 \% \\ 2-\text { Unit on birds } & 26 & 18 \% \\ 3-\text { Unit involving Indians } & 18 & 12 \% \\ 4-\text { Other (specify) } & -\frac{46}{148} & 31 \%\end{array}$

Q30. What did you dislike most about this least favorite activity?

Q31. What could be done to make the camp better if ve have it next year?

Q32. Circle the number next to the statement which best tells what you might say to a friend who is thinking of attending Summer Science Camp.

$\begin{array}{llrr}1 \text { - It was great! I encourage you to go. } & 83 & 55 \% \\ 2 \text { - It was okay. I recommend you go. } & 53 & 35 \% \\ 3 \text { - } & \text { It wasn't anything special. Go if you wart. } & 10 & 7 \% \\ 4 \text { - Boring! Don't go. } & \frac{2}{15} 1 & 1 \% \\ 5 \text { - Yuk! Yuk! And double Yuk! } & & \end{array}$


And now we need a little information about you.

Q33. Your age

$$
\begin{aligned}
& 1-10 \\
& 2-11 \\
& 3-12 \\
& 4-13 \\
& 5-14
\end{aligned}
$$

$\begin{array}{rr}12 & 8 \% \\ 62 & 44 \% \\ 53 & 37 \% \\ 14 & 10 \% \\ 1 & <1 \%\end{array}$

Q34. Your sex
M - Male
F - Female
\begin{tabular}{ll}
82 & $57 \%$ \\
61 & $43 \%$ \\
\hline 143 &
\end{tabular}

Q35. Your race

$$
\begin{array}{ll}
C- & \text { Caucasian } \\
\text { B - Black } \\
\text { - Hispanic } \\
\text { A - Asian } \\
\text { I - Indian (American) } \\
\text { O Other }
\end{array}
$$

$\begin{array}{rr}87 & 67 \% \\ 6 & 5 \% \\ 22 & 17 \% \\ 9 & 7 \% \\ 4 & 3 \% \\ 1 & <1 \%\end{array}$

Q36. Grade in school that you will be going into in the fall

$$
\begin{aligned}
& 1-5 \text { th } \\
& 2-6 \text { th } \\
& 3-7 \text { th } \\
& 4-8 \text { th } \\
& 5-\text { Other }
\end{aligned}
$$

$\begin{array}{rr}14 & 10 \% \\ 68 & 48 \% \\ 53 & 38 \% \\ 3 & 2 \% \\ \frac{3}{141} & 2 \%\end{array}$

Q37. What is your favorite subject in school?

$\begin{array}{ll}1- & \text { Science } \\ 2- & \text { Mathematics } \\ 3- & \text { Physical Education } \\ 4- & \text { Reading } \\ 5- & \text { Writing } \\ 6- & \text { Art } \\ 7- & \text { History } \\ 8- & \text { Spelling } \\ 9- & \text { Other }\end{array}$

\begin{tabular}{rr}
40 & $28 \%$ \\
38 & 250 \\
29 & $20 \%$ \\
11 & $8 \%$ \\
6 & $4 \%$ \\
6 & $4 \%$ \\
5 & $3 \%$ \\
5 & $3 \%$ \\
5 & $3 \%$ \\
\hline 145 &
\end{tabular}

Q38. What school did you attend this past spring?

Registration data is a better source for this information than the survey. 
DOE/RL-93-59, Rev. 0

\section{APPENDIX F-C \\ Responses to Open-Ended Questions \\ IEI Summer Science Camp}

Open-ended questions were asked in the "after" survey.

Q27. Of all the activities throughout the week, which one did you like the BEST?

Q28. What about your favorite unit did you like the best?

Q29. Of all the activities throughout the week, which one did you like the LE, ST?

Q30. What did you dislike most about this least favorite activity?

Q31. What could be done to make the camp better if we have it next year? 
Q27. Of all the activities throughout the week, which one did you like the best?

\section{Owl Pellets / dissecting}

Dissecting owl pellets

Evidence unit

Owl pellets

Owl pellets

2 Plot study / mapping area

The plot

Mapping area

Mapping area

Drawings

Plot study

Plot

The one where we did the plot

Plot study

3 Project Wild Games

Games

The games

Scavenger hunt

Oh Deer

Salmon run

4 Birds

Unit on birds

Unit on birds

\section{$5 \quad$ Trapping bugs}

Trapping bugs

Traps

Making traps

Trapping 
Q27. Of all the activities throughout the week, which one did you like the best?

6 Weather / acid rain / environment

Environment

Learning about acid rain.

Learning about acid rain

Weather

Acid

Unit on weather

Water cycle and water \& oil

\section{$7 \quad$ Other}

I wasn't here

Walk about

Recycling video

Computers.

Ecology

Lab

Everything

Everything, especially birds 
Q28. What about your favorite unit did you like the best?

\section{Owl pellets / dissecting}

With the owl pellet when we opened it up

Seeing the owl \& hawk \& owl pellets

The dissecting owl pellets.

Dissecting the pellets and seeing the bones.

Owl pellets

The dissecting

Things about owls

Owl pellets

Owl pellets

I like owl pellets.

The owl pellets

The owl pellets

Owl pellets and chemistry

I liked dissecting the owl pellet

The dissecting of the owl pellet.

How owls hunt

Owl pellets

Owl pellets

I liked the birds because they were neat.

The owl pellets

Doing owl pellets

The owl pellets

Owls and owl pellet

The owls and the owl pellet.

I liked the owl pellets.

Dissecting owl pellets

Dissecting owl pellets and $0 i 1$ and water experiments.

I liked doing the pellets

Owl pellets

$2 \quad$ Plot study / soil testing / mapping area

Soil testing

I liked the unit on soils.

Testing the soil for $\mathrm{pH}$.

The map making

Soil Testing

The unit on soils when we put different chemicals in the soil and watched it turn colors.

How they changed colors

The one on the plot

$\mathrm{pH}$ test

Testing the soil

Testing the soil

2 Plot study / soil testing / mapping area (cont.)

The colors they turned

Put the trap in

I enjoyed making the plot out in the desert. 
Q28. What about your favorite unit did you like the best?

Doing tests

Chemistry

I liked soil testing

I liked working on our plot cause I found out about insects, sage brush and weather.

I liked researching and testing and finding out stuff about our 20 by 20 plot, that I never would have known otherwise.

The desert

Going out on the plot and studying the plants and animals

Study on our plot study

I liked the plot

Soil, it was interesting.

$\mathrm{pH}$ test

The chemistry

Soil samples

\section{Project Wild Games}

I liked being outside and see different animals.

I like wildlife (animals) very much. I like the owl and the hawk.

Doing the scavenger hunt

The treats and games.

Scavenger hunt

I liked when we played Oh Deer and went on the scavenger hunt.

\section{$4 \quad$ Birds}

Listening to all the interesting talks about birds.

Learning about how lot of us can save the birds.

About the owls and how they can't turn their heads all the way around.

Because I like birds a lot.

The learning about the birds.

I liked to learn about the birds.

I liked the stuff about birds.

When the bird lady came.

That I got to see the birds.

I enjoyed having Taffy Mercer and the lady from the Audubon Society come talk to us. I also enjoyed dissecting owl pellets.

I liked the birds experiment because you got to do things.

4 Birds (continued)

Birds of prey

The live birds

Unit of birds

I got to see a real live barn owl.

The live hawk and barn owl

The birds

Birds and how they live 
Q28. What about your favorite unit did you like the best?

Bird

When we got to go and see the birds two times.

They brought birds in tn show us.

Seeing the birds and hearing the information

When they talked about the difference within the owls

I liked learning about where they stay and live.

Birds

Looking at the burrowing owl

The difference between the birds. Some are made for speed, some are made for quiet flying.

The Falcon

The birds

How they can train them and know so much about them

Birds

Unit on birds

Where you got to see : live hawk and a live owl. Plus some of the talks.

Learning about the birds' heads

Talking about the their differences.

That birds can only tell themselves only five things.

The birds and made things

Unit on Birds, unit on soils, owl pellets

I liked the birds the best.

\section{$5 \quad$ Trapping bugs}

My favorite unit was when we had a tin can and buried it in the ground in a certain area and catch bugs.

Finding bugs

Traps

Seeing if you caught anything

\section{Weather / acid rain}

I liked making the weather instrument

The weather vane, barometer, and the anemometer.

Water cycle

7 Environmental awareness / recycle, reuse, reduce

How many years it takes for an object to disintegrate

Taught me how to recycle to save Earth.

I liked it because it talked about littering.

\section{Other}

It was just fun.

They're just neat to learn about and with the things they do and how. And the cute guys. 
028. What about your favorite unit did you like the best?

I liked experimenting

Sails are neat.

It was fun.

It was fun and I got to know stuff I never knew before.

It's wasn't dirty nor gross or smelling it was fun and easy.

Interesting

Fun

We got to type and print up what we typed.

It's cool?

All of it

Snacks

It was fun

The analyzing

Just learning about it.

It was interesting to learn about.

Being outside in the environment

I don't know.

$i$ liked the hands-on things

Computers

Don't know

Computers I liked the best.

I want to catch a lizard.

I like the lab because there's interesting stuff.

They're interesting

Al1

Al1

Everything 
Q29. Of all the activities throughout the week, which one did you like the LEAST?

1 Owl pellets

Dissecting ow pellets

Owl pellets

2 Plot study

Plot study

Plot study

Plot. It was confusing and boring.

3 Project Wild Games

Habitat lap sit

4 Birds

Birds

$5 \quad$ Trapping bugs

Bugs

6 Weather / acid rain

Weather

Balloon

Our balloon prediction

$7 \quad$ Environmental awareness

Water \& oil 
029. Of all the activities throughout the week, which one did you like the LEAST?

8 Other

Surveys

Making things

Watching the movie.

Movie

Getting my drawings erased

Speeches

Bananas

The cranberry juice!

Paper work

All

This test

Lecture

9 None / all were fun / Don't know

They were all fun.

(There was not one)

None

None

I liked all of them.

I like all of them.

None

Don't really have one

I don't know

Nothing

None

None

None of them

I like them all.

None

None

I don't know.

None

None

Liked all, had fun.

Nothing 
Q30. What did you dislike most about this least favorite activity?

1 Boring / lecture / not interesting

It was kind of boring. Just didn't interest me.

Lectures

It was not that interesting.

It was boring

We didn't do experiments

It was so boring I fell asleep.

It wasn't that exciting

Because it was boring.

Boring

Learning the same thing twice

Didn't like it because there wasn't so interesting.

Because it was boring. All we did was test the soil.

Boring

It was boring

It was kind of boring

Because it was very boring and weird.

It (the whole thing) was boring.

Kind of boring

The soil unit was short and not very interesting.

It was boring.

It was just too boring.

It wasn't fun enough

Learning the same thing twice

I didn't like listening to all the people give speeches.

Speech

It was just boring

I already know some stuff about birds.

The people who came and talked were boring!!!

We11, I've dissected owl pellets before and doing it again was old hat.

It was boring

Boring

The lecture giver

\section{No Indians}

We didn't get to learn about the Indians. Everything was fun!

Because he did not come

We never did get to see the Indians.

Nothing, they were fun but I wanted to know more about Indians.

There were no Indians

\section{Nothing / Liked everything}

Nothing

I liked the whole thing !!!

Like everything

Don't know

Nothing

Don't know

I liked it all. 
Q30. What did you dislike most about this least favorite activity?

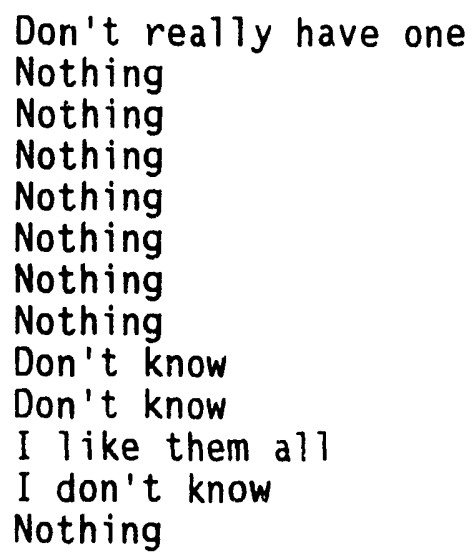

\section{Comments on SSC subjects and activities}

I didn't really enjoy talking about soils.

(GROSS) I hate dissecting. It smelled very bad!

We learn about bugs. I think bugs are gross even though some are helpful

Soil testing

I hate the weeds.

Because we tested dirt and it was dumb.

There wasn't very much information on the soil. We just did soil samples.

The scavenger hunt

I dislike the soils experiment.

I disliked outside work. (It's not my thing!)

It's disgusting touching left overs of an ow 7 .

The deer game

The lady that came to talk

Digging in the dirt

Getting the dirt

Digging in the dirt

I liked some of it, but I would much rather do something on a much bigger animal.

The Audubon

Because we had to take temperatures and make a plot.

I really don't know.

I just didn't like learning about soil. I wanted to learn something else.

Soils, it was not very fun.

Hiding the butterflies

4 Comments on SSC subjects and activities (cont.)

Just watch the bird

The testing

I would have liked to learned more about the birds.

Soils

The games

The owl pellets were fun and gross.

Collecting soils and experimenting

When we had to see what kind of $\mathrm{pH}$ they had.

The birds 
Q30. What did you dislike most about this least favorite activity?

Going through the weeds and digging for dirt.

\section{$5 \quad$ Other}

It was not there.

They're a waste

We had them come at the start of SSC and then they came again and said the same stuff.

We didn't do it.

Too many stickers and too many people

Look up

Look up

We didn't really get into it.

I had to redraw them.

Only getting to use one test tube.

Not enough time

Sticker in my shoe

It was kind of too hard to understand.

It was stupid

Standing around

Not enough space

Eating it

We didn't do it

YUCK!

It's not that I didn't like it. It's because we didn't get to do it. Because we didn't do it

Didn't have it

I did not know what was going on

Because it wasn't that big

My ears hurt

Very confusing

I don't know

The tests

It was too hurried.

Getting dirty

5 Other (continued)

I don't like the paper work. It's because I don't like to write.

Didn't do that

I learned something

I didn't like having to look for a whole bunch of things

I didn't like the dirt

The speaker was childish and thought we were jrd graders.

We didn't do it.

Did not like the plants. 
031. What could be done to make the camp better if we have it next year?

1 Food/snack changes

Better snacks (ha ha) It was great!

More food

More food

Better snacks and drinks

More candy!

Everybody gets their own soil kit and get $\mathrm{Hi}-\mathrm{C}$ fruit drinks instead of cranberry or apple. More time to dissect the owl pellets.

Bigger snacks

No bananas

Not have cranberry juice

More juice

Have bigger snacks.

Let the kids have better snack juices.

A little free time to buy stuff (like pop) and no more cranberry juice.

Better snacks

Better snacks

To not have any cranberry juice anymore

\section{More hands-on activities}

I don't isnow. More activities, and mostly better weather!

Do experiments every day

More hands on \& ? ab work

Add mere science activities

Not so boring.

More live animal stuff and more hands-on stuff.

More hands-on things

More science stuff

More experiments

More projects.

\section{More games}

Make funner activities and same teachers in the same room.

Play more games

To do more fun things

Put more funner things to do.

Have funner

Add funner stuff

Playing more games.

Play more games

\section{$4 \quad$ Curriculum changes}

Pick some more interesting topics.

More stuff on history of the site

More things about animals

Do not dissect owl pellets. 
Q31. What could be done to make the camp better if we have it next year?

Don't have weather.

Have more activities involving chemistry in the $1 a b$.

Get more animals.

Chemicals!!!

Work with more chemicals.

Field trips

Have more animals come here.

More chemistry

More dissecting, more chemistry, more things that have to do with marine

biology.

To talk more about acids

Help life in the plot areas so more kids can see it.

Study different subjects so people will come back that had already been.

Do lots of experiments.

I could learn physics or chemistry

Seeing chemicals more.

The same thing but different experiments.

Less on soils and no bird talks by the last lady that did the last talk

To use chemicals

Field trips

In depth more.

Dissect frogs or other stuff

Do experiments on bugs and pets.

\section{Less lectures, school-1ikeness}

Not have long speeches speakers

Make it less like school. Have more games about...

Less speakers and more hands-on work.

No lecture, longer

6 Change facilities, times, etc.

Different time - all day if possible. Different week or longer week or two.

Make it two weeks long.

Have more classes outside.

Be lenger

More room, longer

6 Change facilities, times, etc. (cont.)

More time, days

Smaller class

To be more organized

Longer time

Have more room when we get into a big group.

Have it longer

Make it longer.

Make the days shorter

Longer

Make it for 3 weeks and more experiments.

Make 5 weeks 
031. What could be done to make the camp better if we have it next year?

You could speed it up some.

Make it longer.

Make it longer

Have it be longer

Have it longer.

Explain the plot better, 2 weeks instead of one.

Give us soil testers

Haye it longer.

Longer period

Make it two weeks instead of one.

Throw in more time.

Do it at a smaller place so people can find where they are supposed to be easier. Send a letter home telling what group they're going to be in.

Have it longer and have more about plants and animals

Not io do things when it is wet.

Separate each grade.

$M$ re activities and longer.

Longer

7 Nothing / Don't know / Okay as is

Nothing

I don't know.

I think that the camp is very nice already.

It was $0 . K$.

It's fine

Don't know

Nothing

Don't know

Nothing

I don't know

I don't know

It's fine the way it is.

7 Nothing / Don't know / Okay as is (cont.)

Nothing

Nothing, keep it same. Just don't play the sitting on lap and making chain game.

It's great. Don't do anything.

Nothing

It is great as it is.

Nothing

Nothing

\section{$8 \quad$ other}

Put people in with some people they know and not just strangers.

Maka sure they are able to make it on time

Less surveys

Spending the night.

We could go out to the campus and pick up litter. 
Q31. What could be done to make the camp better if we have it next year?

Make sure every is ineold.(?)

More organized

Don't want to get my drawings erased.

Always write in the journal.

No more surveys

Make sure the Indian doesn't have different plans.

More

Leaders explain more about the things and longer time

To learn about what the kids want to do.

Don't let it rain!!!

Have cable T.V's

More kids

On the traps, we could get to keep what we catch.

No more paper work

Do things we like.

Give us more stuff 
031. What could be done to make the camp better if we have it next year?

APPENDIX F-D

Teachers Survey

\section{IEI Summer Science Camp}

Ju1y 24, 1992

This questionnaire is intended for professional teachirs. Just as you asked your students to complete a questionnaire that will be used to help us measure and improve the Summer Science Camp, we ask you to do the same. Don't put your name on ihis questionnaire. But, like the students, we ask you to tell it like it. is. Your answers are, of course, confidential and will be used only in combination with others. When finished, please give or send to Liz Swinea, Kennewick School District, 200 S. Dayton St., Kennewick, 99336.

Teaching methods include lecture, demonstrations (including field trips), and "hands-on" activities. Some teachers want to use more of the latter two methods which involve students. But subject content, curriculum, and amount to be covered often force greater use of lecture. Think, for a moment, of just the time you spend in actually teaching. Please consider your relative use of these methods in teaching.

Q1. About what percentage of your actual teaching time in school do you typically spend lecturing?

$\begin{array}{llll}1-\text { Under } 25 \% & 3 & 30 \% \\ 2-25 \%-50 \% & 4 & 40 \% \\ 3-51 \%-75 \% & 3 & 30 \% \\ 4-76 \%-90 \% & 0 & -- \\ 5-91 \%-100 \% & 0 & --\end{array}$

Q2. About what percentage of your actual teaching time in school do you typically spend in demonstrations, field trips, etc.

$\begin{array}{llll}1-\text { Under } 10 \% & 2 & 29 \% \\ 2-11 \%-25 \% & 3 & 30 \% \\ 3-26 \%-50 \% & 4 & 40 \% \\ 4-51 \%-75 \% & 0 & -- \\ 5-76 \%-100 \% & 1 & 10 \%\end{array}$

Q3. About what percentage of your actual teaching time in school do you typically spend with students working with "hands-on" activities?

$1-\quad$ Under $10 \%$
$2-11 \%-25 \%$
$3-26 \%-50 \%$
$4-51 \%-75 \%$
$5-76 \%-100 \%$

$\begin{array}{ll}0 & -\cdots \\ 3 & 30 \% \\ 4 & 40 \% \\ 2 & 20 \% \\ 1 & 10 \%\end{array}$


031. What could be done to make the camp better if we have it next year?

Q4. In addition to lecture, demonstrations, and "hands-on" activities, what other methods do you typically use in teaching? Please indicate the approximate percentage of teaching time you typically devote to each additional method.

Q5. In working with the Summer Science Camp, about what percentage of your actual teaching time did you typically spend lecturing?

$1-\quad$ Under $25 \%$
$2-25 \%-50 \%$
$3-51 \%=75 \%$
$4-76 \%-90 \%$
$5-91 \%-100 \%$

$\begin{array}{ll}9 & 90 \% \\ 1 & 10 \% \\ 0 & --- \\ 0 & --- \\ 0 & ---\end{array}$

Q6. In working with tive Summer Science Camp, about what percentage of your actual teaching time did you typically spend in demonstrations, field trips, etc.

$\begin{array}{llll}1-\text { Under } 10 \% & 1 & 10 \% \\ 2-11 \%-25 \% & 5 & 50 \% \\ 3-26 \%-50 \% & 1 & 10 \% \\ 4-51 \%-75 \% & 1 & 10 \% \\ 5-76 \%-100 \% & 2 & 20 \%\end{array}$

Q7. In working with the Summer Science Camp, about what percentage of your actual teaching time did you typically spend with students working with "hands-on" activities?

$\begin{array}{llll}1-\text { Under } 10 \% & 0 & --\overline{10 \%} \\ 2-11 \%-25 \% & 1 & 10 \% \\ 3-26 \%-50 \% & 3 & 30 \% \\ 4-51 \%-75 \% & 2 & 20 \% \\ 5-76 \%-100 \% & 4 & 40 \%\end{array}$

Q8. In your opinion, what is more important for a teacher to have -- an excellent grasp of the subject matter or a love in working with students?

1 - An excellent grasp of subject matter

2 - Love in working with students

$\begin{array}{ll}2 & 20 \% \\ 8 & 80 \%\end{array}$

Q9. In working with your Hanford and CBC partners, did you gain new knowledge or information on technical or other matters which might be useful to you in the classroom next year?

$\begin{array}{lll}1-\text { Yes } & 6 & 66 \% \\ 2 \text { - No (SKIP TO Q11) } & 3 & 33 \%\end{array}$

Q10. What new knowledge or information did you learn from this experience? 
Q31. What could be done to make the camp better if we have it next year?

Q11. If you had the opportunity, would you want to participate in another Summer Science Camp?
1 - Yes, definitely
$8 \quad 80 \%$
2 - Yes, probably
3 - Uncertain
4 - Probably not
5 - Definitely not
$2 \quad 20 \%$
$0 \quad---$
0

Q12. What would you suggest be done to improve the program?

Q13. Please comment on your experience in this program.

Q14. What grade level do you usually teach?

$\begin{array}{lll}1-\text { Elementary } & 4 & 50 \% \\ 2-\text { Middle school } & 2 & 25 \% \\ 3-\text { High School } & 2 & 25 \%\end{array}$


Q31. What could be done to make the camp better if we have it next year?

\author{
APPENDIX F-E \\ Non-Teachers Survey \\ IEI Summer Science Camp
}

July 24, 1992

This questionnaire is intended for Hanford employees and other non-teachers. Just as you asked your students to complete a questionnaire that will be used to help us measure and improve the Summer Science Camp, we ask you to do the same. Don't put your name on this questionnaire. But, like the students, we ask you to tell it like it is. Your answers are, of course, confidential and will be used only in combination with others. When finished, please give or send to Liz Swinea, Kennewick School District, 200 S. Dayton St., Kennewick, 99336.

Q1. In working with your teacher partners, did you gain new knowledge or information on technical or other matters which might be professionally useful to you in the work place?
1 - Yes
2 - No (SKIP TO Q3)
$1493 \%$
$1 \quad 7 \%$

Q2. What new knowledge or information did you learn from this experienc??

Q3. If you had the opportunity, would you want to participate in another Summer Science Camp?

$\begin{array}{lrl}1 \text { - Yes, definitely } & 12 & 80 \% \\ 2 \text { - Yes, probably } & 3 & 20 \% \\ 3 \text { - Uncertain } & 0 & --- \\ 4 \text { - Probably not } & 0 & --- \\ 5 \text { - Definitely not } & 0 & --\end{array}$

Q4. What would you suggest be done to improve the program?

Q5. Please comment on your experience in this program. 
Q31. What could be done to make the camp better if we have it next year?

\section{APPENDIX F-F}

\section{Parents Survey}

\section{IEI Summer Science Camp}

Thank you for allowing Westinghouse the privilege of working with your child on some special science projects. We hope your child learned something and had fun. Would you please take a few minutes to give us your opinions. This will help us do a better job for your children in the future. Your responses are completely confidential. Please do not sign your name.

1. Have you been aware that your child have been in a new science program in summer school? (Circle the number next to your answer.)
1 - Yes
2 - No
3 - Not sure

$\begin{array}{rr}74 & 90 \% \\ 6 & 7 \% \\ 2 & 2 \%\end{array}$

2. How many children in your family went to the program?
1 - One
$6987 \%$
2 - Two
$10 \quad 13 \%$

3. What was your child's (children's) response(s) to the program?

$\begin{array}{lrr}1 \text { - Very positive } & 77 & 94 \% \\ 2 \text { - Somewhat positive } & 5 & 6 \% \\ 3 \text { - Neither positive nor negative } & 0 & --- \\ 4 \text { - Somewhat negative } & 0 & --- \\ 5 \text { - Very negative } & 0 & ---\end{array}$

4. Would you want your child (children) to participate in this kind of a program next year?
1 - Yes
$8199 \%$
2 - No
3 - Not sure
$0---$

5. How far do you think your child (children) will probably go in school?

1 - Some grade less than high school

2 - Some high school

3 - Graduate from high school

4 - Some college

5 - Graduate from College or more $\quad 70 \quad 85 \%$

6. Have you ever heard of Hanford?

1 - No - PLEASE SKIP TO QUESTION $11 \quad 1 \%$

2 - Yes - CONTINUE WITH NEXT QUESTION $80 \quad 99 \%$ 
DOE/RL-93-59, Rev. 0

This page intentionally left blank. 

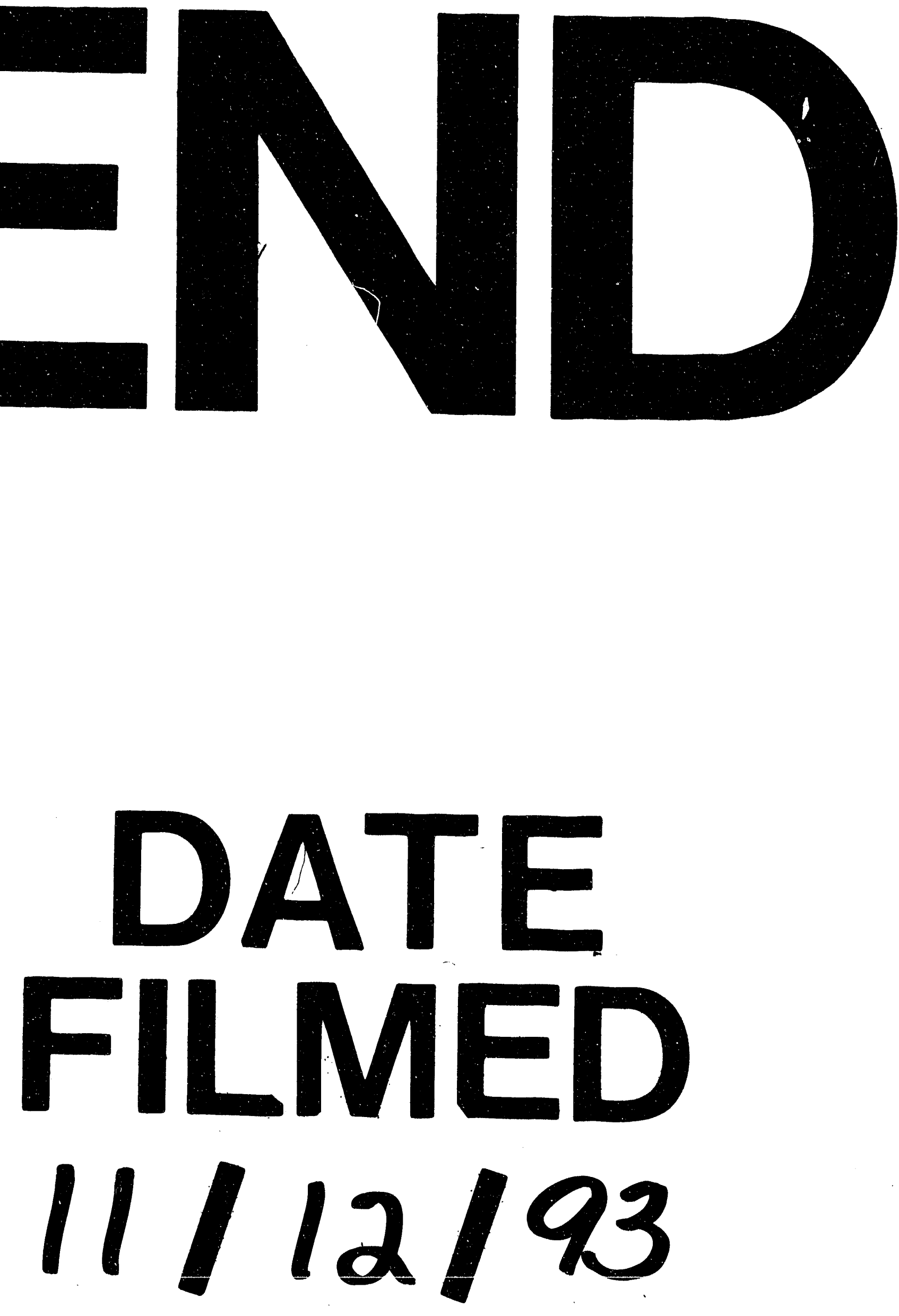
